\title{
Recovery of Cassiterite and Topaz Minerals from an Old Metallurgical Dump, Eastern Desert of Egypt
}

\section{Suzan Sami lbrahim ( $\square$ suzansibrahim@gmail.com )}

Central Metallurgical Research and Development Institute https://orcid.org/0000-0001-7486-2306

\section{Ayman Hagrass}

Tebbin Institute for Metallurgical Studies

khaled Yassin

Central Metallurgical Research and Development Institute

\section{Wael Fathy}

Al-Azhar University

\section{Tawfik Boulos}

Central Metallurgical Research and Development Institute

\section{Research Article}

Keywords: Cassiterite. attrition milling. shaking table. RER dry high intensity magnetic separation

Posted Date: September 8th, 2021

DOl: https://doi.org/10.21203/rs.3.rs-367732/v1

License: (c) (i) This work is licensed under a Creative Commons Attribution 4.0 International License. Read Full License

Version of Record: A version of this preprint was published at Journal of Minerals and Materials Characterization and Engineering on January 1st, 2022. See the published version at https://doi.org/10.4236/jmmce.2022.101005. 


\section{Abstract}

Huge amounts of tailing dumps as a result of mines' blasting operations were impacting both economical and environmental problems. This issue was in serious need to be treated with suitable solutions. Evaluation of one of these tailing dumps in the Eastern Desert of Egypt showed the presence of reasonable amount of cassiterite mineral reaching $0.199 \%$. The mineral was found as finely disseminated particulates within varieties of quartz-feldspar-hornblende-biotite granitic formations.

In the present study, the processing regime relied upon the synergy between reaching liberation size, and mineral over grinding due to its extreme brittleness. However, delicate grinding via attrition scrubbing was adopted to produce $-0.51+0.074 \mathrm{~mm}$ attrition product with fine fractions, reaching $62.31 \%$ and $37.59 \%$, respectively.

The recovery of cassiterite from the $-0.50+0.074 \mathrm{~mm}$ size fraction was accomplished by the physical difference between mother granitic formations that shielded the mineral grains. Under these conditions, joint shaking table/dry high intensity magnetic separation techniques were conducted to recover cassiterite mineral. The CCD statistical system was used as a mathematical approach to optimize the effect of the main working parameters of the magnetic separator, i.e., splitter inclination angle, and belt speed, and their interactions on the cassiterite recovery of the final concentrate. The suggested flow sheet succeeded to recover cassiterite mineral with a grade reaching $11.25 \% \mathrm{SnO}_{2}$ with $94.08 \%$ operational recovery from a feed contained $0.19 \% \mathrm{SnO}_{2}$. These results are highly imperative to achieve applicable processing flow-sheet of such kind of minerals' secondary resources.

\section{Introduction}

The Egyptian Eastern Desert contains very large quantities of mine blasting remnants which are accumulated after different mining operations to extract valuable minerals. In fact, many of the scientific studies have succeeded to a large extent in developing research plans to concentrate many important minerals from these wastes such as gold, silver, copper, lead and zinc, and other important ores. However, very few studies have been devoted to recover the mineral cassiterite Fig. 1. In Egypt, tin deposits are classified as mineralization related to plutonic rocks by either as albite-muscovite granites of calc-alkaline to pera-lkaline affinity having disseminated $\mathrm{Ta}-\mathrm{Nb}-\mathrm{Sn}$ in Abu Dabbab area, as pegmatites related to late granites having $\mathrm{Sn}, \mathrm{Be}, \mathrm{Mo}, \mathrm{U}, \mathrm{Th}, \mathrm{Nb}$, REE mineralization, or as quartz-carbonate veins related to granite cupolas having Au, Sn, W, Mo, Be and F in Igla area (El Aref et al. 2020).

Cassiterite is considered to be the only economically significant tin mineral in the earth's crust. The mineral is hard and heavy but also extremely brittle. Cassiterite has the chemical formula $\mathrm{SnO}_{2}(78.8 \%$ Sn, and $21.2 \% \mathrm{O}_{2}$ ), density of $7.02 \mathrm{~g} / \mathrm{cm}^{3}$, and Mohs hardness $6-7$. Cassiterite is of black, brown-black, yellowish brown, reddish brown coloration. It is nonmagnetic and conductive for electricity (Yang et al. 2014; Angadi et al. 2015; Kumar et al. 2019). 
Cassiterite is mainly enriched in the "tin granites," which contain approximately 15-50 g Sn/ton. Cassiterite also occurs as "mine tin" in domes of granite intrusions, in feldspar topaz granites, and titanomagnetite deposits. Because cassiterite is very resistant to all weathering influences, it is a typical placer mineral. There are no specifications for commercial concentrates of cassiterite because cassiterite is always smelted directly, depending on the concentration, without further treatment (Nandi et al. 2019; Dalimunthe et al. 2020).

Unfortunately, the relative high hardness is accompanied by the unfortunate quality of extreme brittleness. This factor must be taken into account during the crushing and grinding operations prior to concentration (Yang et al. 2019). This is because significant quantities of very fine particles are produced at these steps, resulting in losses of tin in the succeeding processing stages. Therefore, the general policy is that cassiterite grains should, where possible, be recovered at the earliest possible stage and at their largest size to avoid softness that is difficult to handle (Falcon 1982).

It is obvious from the physical characteristics of cassiterite that its high relative specific gravity in relation to its accompanied gangue constituents makes it an ideal mineral for the application of gravityseparation techniques. Development of cassiterite beneficiation techniques has been carried out using flotation, electro and bio- flotation (Sreenivas and Padmanabhan 2002; Pecina et al. 2009; Bulatovic 2010; Gonzales et al. 2013; Gerald et al. 2013; Zhou et al. 2014; Yang et al. 2014; Tian et al. 2017a; Tian et al. 2017b; Tian et al. 2018a; Tian et al. 2018b; Tian et al. 2018c; Tian et al. 2018e; Tian et al 2019; Zhang et al. 2021). Cassiterite was separated using magnetic separation (Wills and Napier-Munn 2006; Lungu 2009; Jiao et al. 2011; Li and Yang 2016; Zeng et al. 2015; Zong et al. 2018; Slusarek and Zakrzewski 2012; Zeng et al. 2015; Hisayoshi et al. 2016; Dimova et al. 2019; Shvedchykova et al. 2020). Hydrometallurgical separation, and microwave pre-treatment were adapted to recover cassiterite mineral and tin metal (Nakahiro and Wakamatsu 1993; Egbe et al. 2013; Ajaka et al. 2014; Mouedhen et al. 2018; Yang 2014; Saisinchai et al. 2016; Zhang et al. 2021).

Figure 1.Occurrences of cassiterite deposits in the Eastern Desert of Egypt (EGSMA 1998)

\section{Experimental}

A technological sample from the tailing dumps of the Eastern Desert of Egypt was supplied for evaluation and treatment. The sample was about $-6 \mathrm{~mm}$ in size. It was subjected to elemental evaluation using XRF unit model PANalytical-Axios, and Perkin-Elmer Analyst 200 atomic absorption. The phase analysis of the sample was applied using X-ray diffract-meter model "pw 1010" with CuKa radiation under target voltage $40 \mathrm{kV}$ and current $30 \mathrm{~mA}$ in a scanning rate of $5^{\circ} 2 \theta / \mathrm{min}$. Scanning electron microscope (SEM) of the type JEM-1230, JEOL equipped with energy dispersive X-ray (EDX) spectrometers was used to evaluate the final products.

A representative sample at the size fraction $-6.0+2.28 \mathrm{~mm}$ from the original sample (about $14 \%$ by wt. of the original sample) was divided into different samples cuts according to grain color. Polished sections of these samples were prepared for reflected light microscope investigation. 
Size reduction of the original sample was conducted via wet grinding attrition technique using Union Process "Attritor" model 1S. The attrition time was conducted for 15 min as three steps, in closed circuit with $0.50 \mathrm{~mm}$ vibrating screen. The impeller speed was $1500 \mathrm{rpm}$, and the solid/water/balls ratio was $1 / 1 / 1$ by wt. (each was $800 \mathrm{~g}$ ). The grinding zirconium ball diameter was $2 \mathrm{~mm}$. The ground product was further screened on $0.074 \mathrm{~mm}$ sieve. Both the over and under screens products were collected, dried, and directed to evaluation. The under screen $-0.074 \mathrm{~mm}$ fines was kept aside for separate study. The over screen product was further divided into $-0.5+0.211 \mathrm{~mm}$ and $-0.211+0.074 \mathrm{~mm}$ fractions for gravity and magnetic separation treatment, separately.

The sample under study could be grouped according to density into light minerals and heavy minerals. The lights included albite, quartz, clinochlore, and talc with average density $2.65 \mathrm{~g} / \mathrm{cc}$. On the other side, heavy minerals included hornblende, tremolite, and biotite with average density $3.50 \mathrm{~g} / \mathrm{cc}$. The difference in density in this case was about 1.52 which was suitable for efficient table separation of this sand sized sample $-0.51+0.074 \mathrm{~mm}$. However, the presence of included heavy cassiterite grains (density reaching 8 $\mathrm{g} / \mathrm{cc}$ ) in addition to other heavy metals like iron, zinc, and copper that were imbedded in the structure of the heavy granites may increase the probability for efficient separation by gravity techniques.

The size fractions $-0.51+0.211 \mathrm{~mm}$ and $-0.211+0.074 \mathrm{~mm}$ were subjected separately to a "Wilfley" shaking table. Throughout the experiments, the sample was kept in suspension at $20-25 \%$ of solids by weight by mechanical stirring. Increasing of slurry concentration more than $25 \%$ led to over-crowding of the particles in the course of separation which deteriorate the separation efficiency. However, the slurry was fed onto an inclined plate at feeding rate of $1.30 \mathrm{~kg} / \mathrm{min}$. The wash water flow rate was kept at 20 $\mathrm{l} / \mathrm{min}$ with table speed in the vicinity of $300 \mathrm{rpm}$. Stroke length and deck inclination were optimized during the separation study.

The middling products after the separation of the two fractions $-0.51+0.211 \mathrm{~mm}$ and $-0.211+0.074$ $\mathrm{mm}$ were further subjected to tabling at relatively lesser wash water flow rate, lesser tilt, and a shorter stroke length than the primary separation working conditions. An increase in the wash water flow rate shows increase in the grade of the concentrate fraction at both lower and higher feed flow rates. As wash water flow rate increases, the transport of gangue minerals to the tailings fraction increases which in turn improves the grade of the concentrate fraction. Higher grade of the concentrate fraction is obtained at higher level of both deck tilt angle and feed flow rate. With a lower level of deck tilt angle, an increase in the feed rate decreases the quality of the concentrate fraction (Wills and Napier-Munn 2006; Tripathy et al. 2010; Egbe et al. 2013; Ajaka et al. 2014; Mouedhen et al. 2018).

At the end of shaking table process, various products were collected, dried, and directed to evaluation. The well dried products were fed separately onto laboratory Eriez RER dry high intensity magnetic separator at permanent field strength of 21,000 gauss. Feeding rate was adjusted at $2 \mathrm{~kg} / \mathrm{hr}$. BoxBehnken Design (BBD) was constructed to determine effect of the separator splitter inclination and belt speed and their interactions on the cassiterite recovery\% as the sole response of this design, and to identify its optimum conditions as well, Table 1. 
The $2^{k}$ factorial design, which is basically a series of tests containing $k$ factors, each of which has two levels ('low' and 'high'). The target a factorial experiment is mainly to determine the factor effects on the process output. Understanding factor effects helps to adjustment of these factors to optimize the process output. The effect of each factor on the process output can be due to single factor effect and/or its interaction with one or more from the other factors (interactive effects). The magnitude and sign of the numerical values of different effects coefficients give good idea about how these effects influence the process output. A higher value for an effect coefficient means that the factor affects the process output significantly. A positive and negative signs means that increasing the level(s) of the factor(s) will increase or decrease the output of the process respectively.

Software package, Design-Expert 6.0.5, Stat-Ease, Inc., Minneapolis, USA, was used for regression analysis of experimental data and to plot the response surface (Box and Behnken 1960). Analysis of variance (ANOVA) was used to estimate the statistical parameters. The extent of fitting the experimental results to the polynomial model equation was expressed by the determination coefficient, R2. F-test was used to estimate the significance of all terms in the polynomial equation within $95 \%$ confidence interval. The products after magnetic separation were directed to evaluation.

Table 1

Levels of the two variable parameters

\begin{tabular}{|llllll|}
\hline Variable & Symbol & Unit & $(\boldsymbol{( )}$ & $\mathbf{( 0 )}$ & $\mathbf{( + )}$ \\
\hline Splitter angle & A & degree & 70.00 & 72.50 & 75.00 \\
\hline Belt speed & B & rpm & 100 & 150 & 200 \\
\hline
\end{tabular}

\section{Results And Discussion}

\section{Sample characterization}

Results of XRF analysis showed that $\mathrm{SnO}_{2}$ constituted $0.199 \%$ of the sample. The major oxides were $\mathrm{SiO}_{2}, \mathrm{Al}_{2} \mathrm{O}_{3}, \mathrm{MgO}, \mathrm{Fe}_{2} \mathrm{O}_{3}$, and $\mathrm{CaO}$. The oxides contents assayed $51.94 \%, 11.87 \%, 10.97 \%, 8.73 \%$, and $5.68 \%$, respectively, Table 2 . They were related to different minerals phases, e.g. albite, quartz, tremolite, clinochlore hornblende, biotite, and talc, Fig. 2. According to XRD pattern, semi quantitative analysis, these phases represented about $27.30 \%, 22.8 \%, 12.30 \%, 21.90 \%, 11.70 \%$, and $4.00 \%$, respectively, of the original sample, Fig. 2. Rare earth oxides e.g. $\mathrm{ZrO}_{2}, \mathrm{Rb}_{2} \mathrm{O}, \mathrm{SrO}$, and $\mathrm{Nb}_{2} \mathrm{O}_{5}$ assayed $0.021 \%, 0.014 \%$, $0.014 \%$, and $0.002 \%$ were identified, Table 1 . Amounts of nickel, copper, and zinc oxides were detected, Table 2.

Size/chemical analyses of the original sample (as received) are shown in Table 3. It is clear that cassiterite showed concentration in SnO2 reaching $0.39 \%-0.25 \%$ in $0.59-0.074 \mathrm{~mm}$ fractions, Table 2 . Fewer cassiterite concentrations assayed $0.17-0.11 \% \mathrm{SnO}_{2}$ were noted in coarser fractions $6.0-0.83 \mathrm{~mm}$, 
and in the finer fraction $-0.074 \mathrm{~mm}$, Table 3 . On the other hand Table 3 illustrates the size/chemical analyses of the attrition product. It was noted that low content of fines below $0.074 \mathrm{~mm}$ reaching about $15 \%$ by wt., were produced after the attrition process, Table 4 . The constitution of these fines besides cassiterite may include the soft minerals e.g. talc and clinochlore.

Results of sink/float tests using bromoform (sp.g. $2.89 \mathrm{~g} / \mathrm{cc}$ ) showed that $24.40 \%$ and $21.40 \%$ by weight of the attrition $-0.51+0.211 \mathrm{~mm}$, and $-0.211+0.074 \mathrm{~mm}$ samples were separated as heavy products with increase in $\mathrm{MgO}$ from 10.97-13.38\%, $\mathrm{TiO}_{2}$ from $0.75-1.02 \%, \mathrm{Cr}_{2} \mathrm{O}_{3}$ from $0.17-0.47 \%$, and $\mathrm{Fe}_{2} \mathrm{O}_{3}$ from $8.73-14.38 \%$, Table 5. On the other hand, the silica and alumina contents assayed $46.16 \% \mathrm{SiO}_{2}$, and $10.04 \% \mathrm{Al}_{2} \mathrm{O}_{3}$, respectively, Table 5 . The increase in content of these oxides may be attributed to the presence of tremolite, hornblende, and biotite granites in the sink fraction. Meanwhile, $\mathrm{SnO}_{2}$ content increased from $0.199 \%$ in the original sample to $0.76 \%$ in the sink product, Table 5 . This showed that almost all the cassiterite content in the original sample was concentrated as inclusions of different concentrations within the matrices of these heavy minerals.

Different samples cuts that were picked from the $6.0-2.28 \mathrm{~mm}$ original sample according to grain color were illustrated in Fig. 3. The petrography investigation of polished sections of these stones cuts showed that cassiterite inclusions were found almost throughout all the minerals matrices granitic formations in different concentrations and with various diameter sizes between 120 microns to 5 microns as shown in Fig. 4. as follows:

- Thin veins and grains of cassiterite (from 20 to 120 um) found in the fractured quartz Fig. 4. A.

- Patches of cassiterite (from 30 to 5 um in diameter) coating the surface of biotite, Fig. 4.B.

- Finely disseminating elongate crystals of cassiterite (from 10 to 5 um diameter) found in groundmass of Hornblende and Biotite, Fig. 4.C.

- Large crystal of cassiterite "Hexagonal" (150 um diameter), Fig. 4.D.

- Very large crystal of cassiterite (from 200-250 um diameter), Fig. 4.E.

- Large cassiterite particle (120 um diameter) and large vein of cassiterite found between biotite and hornblende (light brown in color), Fig. 4.F.

- Grains of cassiterite (from 40-120 um in diameters) found in the open space between quartz and microcline, Fig. 4.G.

- Grains of cassiterite (from 40-120 um in diameters) found in the open space between quartz and microcline (yellow brown in color), Fig. 4. $\mathrm{H}$ and I.

- Large grains of elongated cassiterite and topaz minerals were detected together in the 400 microns particle size, Fig. 4.J. 
Table 2

XRF elemental analysis of the original sample

\begin{tabular}{|llll|}
\hline Oxide & $\mathrm{Wt} \%$ & Oxide & $\mathrm{Wt} \%$ \\
\hline $\mathrm{Na}_{2} \mathrm{O}$ & 0.615 & $\mathrm{NiO}$ & 0.083 \\
\hline $\mathrm{MgO}$ & 10.967 & $\mathrm{CuO}$ & 0.011 \\
\hline $\mathrm{Al}_{2} \mathrm{O}_{3}$ & 11.869 & $\mathrm{ZnO}$ & 0.008 \\
\hline $\mathrm{SiO}_{2}$ & 51.939 & $\mathrm{As}_{2} \mathrm{O}_{3}$ & 0.000 \\
\hline $\mathrm{P}_{2} \mathrm{O}_{3}$ & 0.292 & $\mathrm{Rb}_{2} \mathrm{O}$ & 0.014 \\
$\mathrm{SO}_{3}$ & 0.031 & $\mathrm{SrO}$ & 0.014 \\
\hline $\mathrm{K}_{2} \mathrm{O}$ & 1.490 & $\mathrm{ZrO}_{2}$ & 0.021 \\
\hline $\mathrm{CaO}^{2}$ & 5.683 & $\mathrm{Nb}_{2} \mathrm{O}_{5}$ & 0.002 \\
\hline $\mathrm{TiO}_{2}$ & 0.754 & $\mathrm{SnO}_{2}$ & 0.199 \\
\hline $\mathrm{Cr}_{2} \mathrm{O}_{3}$ & 0.175 & $\mathrm{PbO}$ & 0.007 \\
\hline $\mathrm{MnO}$ & 0.402 & $\mathrm{Cl}$ & 0.004 \\
\hline $\mathrm{Fe}_{2} \mathrm{O}_{3}$ & 8.730 & & \\
\hline
\end{tabular}


Table 3

Size/chemical analysis of the original sample (as received)

\begin{tabular}{|lllllll|}
\hline Fraction, mm & Wt.\% & Cum.Wt.\% & $\mathrm{SiO}_{2} \%$ & $\mathrm{Al}_{2} \mathrm{O}_{3} \%$ & $\mathrm{Fe}_{2} \mathrm{O}_{3} \%$ & $\mathrm{SnO}_{2} \%$ \\
\hline$-6.0+1.168$ & 14.60 & 14.60 & 47.66 & 5.25 & 7.66 & 0.17 \\
\hline$-1.168+0.833$ & 11.00 & 25.76 & 47.66 & 5.25 & 7.66 & 0.17 \\
\hline$-0.83+0.598$ & 10.10 & 36.66 & 45.52 & 5.65 & 7.39 & 0.38 \\
\hline$-0.59+0.417$ & 10.80 & 47.61 & 49.83 & 5.45 & 7.40 & 0.39 \\
\hline 0.295 & 9.10 & 58.51 & 45.84 & 4.82 & 7.53 & 0.34 \\
\hline 0.208 & 7.40 & 67.14 & 51.12 & 5.15 & 7.87 & 0.31 \\
\hline 0.106 & 4.40 & 80.04 & 51.65 & 7.07 & 7.36 & 0.29 \\
\hline 0.074 & 10.00 & 83.82 & 53.84 & 4.49 & 6.35 & 0.25 \\
\hline-0.074 & 22.60 & 100.00 & 46.18 & 5.37 & 5.91 & 0.11 \\
\hline Total & 100.0 & & 47.52 & & 7.16 & \\
\hline Original & 100.0 & & 51.94 & 11.67 & 8.73 & 0.199 \\
\hline
\end{tabular}

Table 4

Size/chemical analysis of the attrition sample

\begin{tabular}{|llllll|}
\hline Fraction, $\mathrm{mm}$ & $\mathrm{Wt} \%$ & $\mathrm{SiO}_{2} \%$ & $\mathrm{Al}_{2} \mathrm{O}_{3} \%$ & $\mathrm{SnO}_{2} \%$ & Dist., \% \\
\hline$-0.5+0.211$ & 50.75 & 52.91 & 14.09 & 0.179 & 35.71 \\
\hline$-0.211+0.074$ & 11.56 & 55.52 & 6.91 & 0.239 & 10.85 \\
\hline Total & 62.31 & & & 0.190 & 59.49 \\
\hline-0.074 & 37.59 & 51.62 & 8.77 & 0.21 & 40.51 \\
\hline Calculated & 100.00 & & & 0.199 & 100 \\
\hline Original sample & 100.00 & 51.94 & 11.87 & 0.199 & 100 \\
\hline
\end{tabular}


Table 5

XRF analysis of sink fraction of the attrition product $-0.51+0.074 \mathrm{~mm}$

\begin{tabular}{|llll|}
\hline Oxide & $\mathrm{Wt} \%$ & Oxide & Wt\% \\
\hline $\mathrm{Na}_{2} \mathrm{O}$ & 0.51 & $\mathrm{CuO}$ & 0.004 \\
\hline $\mathrm{MgO}$ & 13.38 & $\mathrm{ZnO}$ & 0.012 \\
\hline $\mathrm{Al}_{2} \mathrm{O}_{3}$ & 10.04 & $\mathrm{As}_{2} \mathrm{O}_{3}$ & 0.003 \\
\hline $\mathrm{SiO}_{2}$ & 46.19 & $\mathrm{Rb}_{2} \mathrm{O}$ & 0.010 \\
\hline $\mathrm{P}_{2} \mathrm{O}_{5}$ & 0.17 & $\mathrm{SrO}$ & 0.010 \\
\hline $\mathrm{SO}_{3}$ & 0.02 & $\mathrm{Y}_{2} \mathrm{O}_{3}$ & 0.004 \\
\hline $\mathrm{K}_{2} \mathrm{O}$ & 0.66 & $\mathrm{ZrO}_{2}$ & 0.009 \\
\hline $\mathrm{CaO}^{2}$ & 6.76 & $\mathrm{Nb}_{2} \mathrm{O}_{5}$ & $0 / 006$ \\
\hline $\mathrm{TiO}_{2}$ & 1.02 & $\mathrm{SnO}_{2}$ & 0.759 \\
\hline $\mathrm{Cr}_{2} \mathrm{O}_{3}$ & 0.47 & $\mathrm{PbO}$ & $0 / 012$ \\
\hline $\mathrm{MnO}^{2} 0.65$ & $\mathrm{Cl}$ & 0.001 \\
\hline $\mathrm{Fe}_{2} \mathrm{O}_{3}$ & 14.38 & $\mathrm{Br}$ & 0.012 \\
\hline $\mathrm{NiO}$ & 0.104 & & \\
\hline
\end{tabular}

\section{Cassiterite Enrichment Using Shaking Table}

After applying some exploratory experiments on the shaking table separation of the $0.51+0.21 \mathrm{~mm}$ sample, it was noted that at table inclination $3^{\circ}$, and at constant wash water flow rate of $20 \mathrm{l} / \mathrm{min}$., the gradual increase in stroke length from $2 \mathrm{~cm}, 2.5 \mathrm{~cm}$, and to $3 \mathrm{~cm}$ was not accompanied by notable change in mineral recovery, yet an improvement in recovery reaching $82.5 \%$ at stroke length $2.5 \mathrm{~cm}$ was recorded, Fig. 5.

However, at table inclination of $4^{\circ}$, and the wash water flow rate of $20 \mathrm{l} / \mathrm{min}$., no change in recovery (all recovery values were $78-80 \%$. In addition, the results showed again some improvement to reach $85 \%$ at $2.5 \mathrm{~cm}$ stroke length, Fig. 5. At table inclination $5^{\circ}$, and water wash $20 \mathrm{l} / \mathrm{min}$., again the same behavior as previously noted, no change in recovery $(75 \%-77 \%)$, and again the recovery showed improvement to $88 \%$ at $2.5 \mathrm{~cm}$ stroke length, Fig. 5 . At constant table tilt $5^{\circ}$ and stroke length $2.5 \mathrm{~cm}$, the wash water flow rate seemed very effective on the mineral recovery. Gradual decreasing of water rate from $25 \mathrm{l} / \mathrm{min}$. to 20 
$\mathrm{l} / \mathrm{min}$., and $15 \mathrm{l} / \mathrm{min}$., the recovery decreased from $89-84 \%$, and then $76 \%$, Table 6 . At constant stroke length $2.5 \mathrm{~cm}$ and at low wash water flow rate at $15 \mathrm{l} / \mathrm{min}$., the recovery gradually decreased from $81-$ $76 \%$ by the gradual increase on the table tilt from $3^{\circ}$ to $5^{\circ}$, Table 6 .

At constant stroke length $2.5 \mathrm{~cm}$ and wash water flow rate $20 \mathrm{l} / \mathrm{min}$., it was noted that the change in the table tilt showed no effect on the level of cassiterite recovery. Whereas by increasing the tilt from $4^{\circ}$ to $5^{\circ}$, the recovery percentage remained un-changeable at the level of $85 \%$, Table 6 . At constant stroke length $2.5 \mathrm{~cm}$, and wash water flow rate reaching $15 \mathrm{I} / \mathrm{min}$, the recovery percentage decreased from $81-76 \%$ by decreasing the inclination from $4^{\circ}$ to $5^{\circ}$. Meanwhile, at wash water flow rate reached $20 \mathrm{l} / \mathrm{min}$., there was no change on the recovery $\%$ by changing the table tilt from $4^{\circ}$ to $5^{\circ}$, Fig. 6 . This information proved again that the wash water flow rate was a detrimental parameter on the table separation efficiency. As the wash water flow rate increased, the transport of gangue minerals to the tailings fraction increased which in turn improved the grade of the concentrate fraction. Moreover, higher grade of the concentrate fraction was obtained at higher level of deck tilt angle and feed flow-rate. With a lower level of deck tilt angle, an increase in the feed rate decreased the quality of the concentrate fraction.

However, the black to deep gray strip of heavy concentrate fraction was discharged over the far end of the deck, Fig. 7. In addition, great amount of middling mass composed of two distinguished colors (light gray and beige) were formed on the table surface. The gray mass was shown to contain most of the heavy minerals that constituted the original sample, i.e. hornblende, biotitie, and tremolite, Fig. 7. Additionally, the middling beige in color mass was composed of light minerals which contained cassiterite inclusions i.e. quartz, and feldspars (albite, and microcline), Fig. 7. On the other hand, fragments of these light minerals that were nearly free from cassiterite inclusions were carried by the flowing water towards the tailings launder, Fig. 7. However, the variation in color between these cuts helped a lot in their identification.

It could be concluded that the coarse fraction $-0.5+0.21 \mathrm{~mm}$ was stratified in a good manner at table inclination $5^{\circ}$, stroke length $2.5 \mathrm{~cm}$, and table speed $280-300 \mathrm{rpm}$. In case of applying the finer fractions $-0.21+0.074 \mathrm{~mm}$, the suitable stroke length was reduced to $2 \mathrm{~cm}$ with increased table speed up to about 320-330 rpm. Usually the increase in the length of the stroke required a decrease in the number of strokes per minute and vice-versa to achieve efficient separation. High amplitude was necessary when treating relatively coarse particles in order to create complete dilation along with lower acceleration (Burt and Mills 1984). The Schematic Diagram showing the shaking tabling separation process was depicted in Fig. 7 (N.B. in all figures the cassiterite grade\% were multiplied by the factor 50 to facilitate the illustration). The evaluation of the final end-products with respect to cassiterite recovery and grade after shaking table was illustrated in Fig. 8 and Table 6. 
Table 6

Evaluation of shaking table products

\begin{tabular}{|c|c|c|c|c|c|c|c|}
\hline \multirow[t]{2}{*}{ Product } & \multicolumn{3}{|c|}{$-0.51+0.211 \mathrm{~mm}$} & \multicolumn{3}{|c|}{$-0.211+0.074 \mathrm{~mm}$} & \multirow{2}{*}{$\begin{array}{l}-0.51+0.074 \\
\mathrm{~mm} \\
\mathrm{Wt} . \% \mathrm{SnO}_{2} \% \\
\text { Dist., \% }\end{array}$} \\
\hline & Wt.\% & $\mathrm{SnO}_{2} \%$ & $\begin{array}{l}\mathrm{SnO}_{2} \% \\
\text { Dist. }{ }_{\text {opt }} \text {. }\end{array}$ & Wt.\% & $\mathrm{SnO}_{2} \%$ & $\begin{array}{l}\mathrm{SnO}_{2} \% \\
\text { Dist. }{ }_{\text {opt }}\end{array}$ & \\
\hline Heavy & 2.66 & 1.45 & 20.30 & 2.10 & 1.98 & 18.08 & \\
\hline $\begin{array}{l}\text { Middling } \\
1\end{array}$ & 23.45 & 0.31 & 39.26 & 2.88 & 1.32 & 16.53 & \\
\hline $\begin{array}{l}\text { Middling } \\
2\end{array}$ & 36.34 & 0.20 & 38.25 & 69.22 & 0.19 & 65.39 & \\
\hline Total & 62.45 & 0.29 & 97.81 & 74.20 & 0.28 & 91.61 & $\begin{array}{l}40.270 .29 \\
96.94\end{array}$ \\
\hline $\begin{array}{l}\text { Light } \\
\text { tailing }\end{array}$ & 37.55 & 0.01 & 1.98 & 27.15 & - & - & \\
\hline Calc. opt. & 100.00 & 0.190 & 100.00 & 100.0 & 0.23 & 100 & \\
\hline Feed & 50.75 & 0.190 & 47.75 & 11.56 & 0.23 & 11.45 & $\begin{array}{l}62.310 .19 \\
60.49\end{array}$ \\
\hline
\end{tabular}

\section{Statistical Optimization Of Rer Magnetic Separation Process}

The design summary and the factorial design results of the RER magnetic separation in terms of cassiterite recovery\% as a response are shown in Tables 7 and 8 . It can be seen that the cassiterite recovery \% reached an optimum of $97 \%$ (runs $2,5,7,8,10$, and 11 ) at splitter angle $72.50^{\circ}$, and belt speed $150.00 \mathrm{rpm}$. A regression Eq. (1) was obtained by multiple regression analysis of the experimental data as follows:

Recovery $\%=-24.76+66.22 * A+0.68 * B-0.44 * A 2-3.00 E-004 * B 2-8.00 E-003 * A * B(1)$

where, $A$ is the splitter inclination angle, and $B$ is the separator belt speed.

The optimization of Eq. (1) was performed using State-Ease program, by an iteration method. Statistical testing of the model has been carried out by F-test to produce ANOVA - the analysis of variance, Table 9. The values of $\mathrm{R}^{2}$ and the standard deviation suggested that there was a good agreement between the experimental and predicted values obtained from the model, Fig. 9. 
Results showed that with increasing the splitter inclination angle and the separator belt speed, cassiterite recovery value increased, and reached its maximum value of $97 \%$ at splitter angle $72.50^{\circ}$ and at belt speed $150 \mathrm{rpm}$. However, it was evident that in these selected ranges of separator angle $\left(70^{\circ}-75^{\circ}\right)$ and belt speed (100-200 rpm), there was a dominant effect of the separator splitter inclination angle on cassiterite recovery \% compared to the effect of belt speed, Fig. 10.

On the other hand, by increasing both splitter inclination and belt speed more than $72.50^{\circ}$ and $150 \mathrm{rpm}$ respectively, a slight decrease in the recovery value reaching $96 \%$ was remarked. Meanwhile, the decrease in the values of both variables to $70^{\circ}$ and $100 \mathrm{rpm}$, respectively, a pronounced decrease in the cassiterite recovery value reaching $86 \%$ was remarked, Fig. 10 . In addition, the interaction of both variables showed a reversible effect on the mineral recovery, Fig. 11. it was noticed that at low belt speed of $100 \mathrm{rpm}$, the increase in splitter angle was accompanied by gradual increase in cassiterite recovery from $86-92 \%$, and then to $96 \%$. However, at belt speed of $150 \mathrm{rpm}$, the change in splitter angle showed promising recovery reaching $90 \%$ at $70^{\circ}$, and then the recovery increased to reach $97 \%$ at splitter angles $75^{\circ}$. Additionally, the same trend was shown by increasing the belt speed to reach 200 rpm, Fig. 12. Response surface for cassiterite recovery\% as function of RER magnetic separation variables, i.e. splitter angle, and belt speed was illustrated in Fig. 13.

An interesting study was carried out about the effect of feed size of both magnetic and nonmagnetic particles on the efficiency of the RER magnetic separator (Gehauf 2004). It was found that, when nonmagnetic particles travel over a roll and are allowed to drop unhindered, they are roughly classified by their particle size. Large particles will travel further from the centerline of the roll than smaller particles. Therefore, large particles are typically processed using lower surface speeds than small particles. When a magnetic roll is used, strongly attached magnetic particles will usually be pinned to the roll surface until they are released from the magnetic field. Weakly attached magnetic particles may only be deflected by the magnetic field, altering them from their normal path. When this occurs, there will be an overlap in the large weakly attached magnetic particles and the small nonmagnetic particles (Gehauf 2004). If the splitter is set to eliminate the large weakly attached magnetic particles, many of the small nonmagnetic particles will report to the magnetic product. On the other hand, if the splitter is set to recover the small nonmagnetic particles, the nonmagnetic product will contain many of the large weakly attached magnetic particles. This is an indication that the particle size range is too great. The problem can normally be overcome by screening the feed before magnetic separation and thus produce a better product. The practicality of screening is ultimately based on the difference in the magnetic responses of the particles to be separated and the value of the product(s). That was the way the present study started, i.e., feed fractionation into $-0.51+0.21 \mathrm{~mm}$ and $-0.21+0.074 \mathrm{~mm}$ (Ibrahim et al. 2017).

However, it could be concluded that the optimum separation conditions were reached by keeping the splitter angle fixed at $72.50^{\circ}$ and by applying the belt speed at $150 \mathrm{rpm}$ for coarse fraction and $200 \mathrm{rpm}$ for finer fraction. At these conditions, the optimum operational concentration results of the $-0.50+0.21$ $\mathrm{mm}$ fraction was $2.10 \%$ wt., $12.96 \% \mathrm{SnO}_{2}$, and $97.62 \%$ recovery from a feed containing $0.29 \% \mathrm{SnO}_{2}$. On 
the other hand, the optimum operational concentration results of the $-0.21+0.074 \mathrm{~mm}$ fraction was $3.72 \%$ wt., $6.21 \% \mathrm{SnO} 2$, and $90.00 \%$ recovery from a feed containing $0.28 \% \mathrm{SnO}_{2}$. From these results, it could be concluded that an overall final cassiterite concentrate contained $11.25 \% \mathrm{SnO}_{2}, 2.29 \% \mathrm{wt}$, and $94.08 \%$ recovery from a feed contained $0.19 \% \mathrm{SnO}_{2}$, was produced, Fig. 14 (N.B. in all figures the cassiterite grade\% were multiplied by the factor 50 to facilitate the illustration).

Important to mention that a non magnetic product containing topaz mineral was separated from the coarse fraction $-0.51+0.21 \mathrm{~mm}$ only at splitter angle of $65^{\circ}$ and belt speed $150 \mathrm{rpm}$. This may be attributed to the presence of topaz that was impeded as inclusions within the hard quartzite matrix that resisted over-grinding and remained in the coarser size $0.50+0.21 \mathrm{~mm}$. SEM/EDX and XRD analyses of topaz mineral, cassiterite/topaz, and cassiterite mineral are illustrated in Figs. 15-21. However, the schematic diagram for the suggested processing flow-sheet to recover cassiterite and topaz minerals from some mines scraps of the Eastern Desert of Egypt is illustrated in Fig. 22.

Table 7

Design summary

\begin{tabular}{|c|c|c|c|c|c|c|c|}
\hline \multicolumn{2}{|l|}{ Stydy type } & \multicolumn{2}{|c|}{ Response surface } & & & & \\
\hline \multicolumn{2}{|c|}{ Experiments } & \multicolumn{2}{|c|}{13} & & & & \\
\hline \multicolumn{2}{|c|}{ Initial design } & \multicolumn{2}{|c|}{ Central composite } & & & & \\
\hline \multicolumn{2}{|l|}{ Blocks } & \multicolumn{2}{|c|}{ No blocks } & & & & \\
\hline \multicolumn{2}{|c|}{ Design model } & \multicolumn{2}{|c|}{ Quadratic } & & & & \\
\hline Responce & Name & Units & Obs & Minimum & Maximum & trans & Model \\
\hline Y1 & recovery & $\%$ & 13 & 86.00 & 97.00 & None & Quadratic \\
\hline Factor & Name & Units & Type & $\begin{array}{l}\text { Low } \\
\text { actual }\end{array}$ & $\begin{array}{l}\text { High } \\
\text { actual }\end{array}$ & $\begin{array}{l}\text { Low } \\
\text { coded }\end{array}$ & $\begin{array}{l}\text { High } \\
\text { coded }\end{array}$ \\
\hline A & $\begin{array}{l}\text { Splitter } \\
\text { angle }\end{array}$ & Degree & Numeric & 70.00 & 75.00 & -1.000 & 1.000 \\
\hline B & Belt speec & $\mathrm{rpm}$ & Numeric & 100.00 & 200.00 & -1.000 & 1.000 \\
\hline
\end{tabular}


Table 8

Results of full factorial design

\begin{tabular}{|llllll|}
\hline Std & Run & Block & $\begin{array}{l}\text { Variable 1 } \\
\text { A: Splitter angle, degree }\end{array}$ & $\begin{array}{l}\text { Variable 2 } \\
\text { B: belt speed, rpm }\end{array}$ & $\begin{array}{l}\text { Response 1 } \\
\text { Recovery \% }\end{array}$ \\
\hline 3 & 1 & Block 1 & 70.00 & 200.00 & 90.00 \\
\hline 8 & 2 & Block 1 & 72.50 & 220.71 & 97.00 \\
\hline 2 & 3 & Block 1 & 75.00 & 100.00 & 96.00 \\
\hline 1 & 4 & Block 1 & 70.00 & 100.00 & 86.00 \\
\hline 9 & 5 & Block 1 & 72.50 & 150.00 & 97.00 \\
\hline 4 & 6 & Block 1 & 75.00 & 200.00 & 96.00 \\
\hline 12 & 7 & Block 1 & 72.50 & 150.00 & 97.00 \\
\hline 10 & 8 & Block 1 & 72.50 & 150.00 & 97.00 \\
\hline 6 & 9 & Block 1 & 76.04 & 150.00 & 96.00 \\
\hline 11 & 10 & Block 1 & 72.50 & 150.00 & 97.00 \\
\hline 13 & 11 & Block 1 & 72.50 & 150.00 & 97.00 \\
\hline 7 & 12 & Block 1 & 72.50 & 79.29 & 86.00 \\
\hline 5 & 13 & Block 1 & 68.96 & 150.00 & 90.00 \\
\hline
\end{tabular}


Table 9

ANOVA for response surface quadratic model in terms of recovery $\%$ as a responce

\begin{tabular}{|llllll|}
\hline Source & Sum of squares & DF & Mean square & F Value & Prob $>$ F \\
\hline Model & 134.63 & 5 & 26.93 & 6.97 & 0.0121 \\
\hline$A$ & 74.94 & I & 74.94 & 19.39 & 0.0031 \\
\hline$B$ & 2.00 & I & 2.00 & 0.52 & 0.4593 \\
\hline$A 2$ & 52.61 & I & 52.61 & 13.61 & 0.0078 \\
$B 2$ & 3.91 & I & 3.91 & 1.01 & 0.3479 \\
$A B$ & 4.00 & I & 4.00 & 1.03 & 0.3429 \\
\hline Residual & 27.06 & 7 & 3.87 & & \\
\hline Lack of Fit & 27.06 & 3 & 9.02 & & \\
\hline Pure Erro & 0.000 & 4 & 0.000 & & \\
\hline Cor Total & 161.69 & 12 & & & \\
\hline
\end{tabular}

\section{Conclusions}

A technological grab rock sample from the mines scraps of the Eastern Desert of Egypt was subjected to chemical and mineralogical investigation. The sample was below $6 \mathrm{~mm}$ in size. It was showed to contain $0.199 \%$ cassiterite mineral $\left(\mathrm{SnO}_{2}\right)$. Cassiterite was found as inclusions of different sizes from 250 microns to 5 microns. These inclusions were imbedded in granitic ground mass containing quartzfeldspar- hornblende-clinochlore-tremolite-biotite- and talc minerals in different concentrations.

Stirring ball milling was adapted to grind the sample into $100 \%-0.51 \mathrm{~mm}$ with minimum fines (as possible) to reach $15 \%$ by wt. of the feeding sample. However, the total fines below $0.074 \mathrm{~mm}$ of the original sample after attrition reached about $37 \%$ by wt. with about $38 \%$ cassiterite distribution. This fine product was kept aside for another beneficiation study.

The attrition $-0.51+0.074 \mathrm{~mm}$ product was shown to contain about $0.19 \% \mathrm{SnO}_{2}$ with cassiterite distribution reached $62 \%$ of the original sample. This product was divided into two fractions, $-0.50+0.21$ $\mathrm{mm}$ and $-0.211+0.074 \mathrm{~mm}$. Each fraction was separately subjected to gravity separation using "Wilfley" shaking table. The coarse fraction $-0.5+0.21 \mathrm{~mm}$ was stratified in a good manner upon the table surface at table inclination $5^{\circ}$, stroke length $2.5 \mathrm{~cm}$, and table speed in the range of $280-300 \mathrm{rpm}$. In case of applying the finer fractions $-0.21+0.074 \mathrm{~mm}$, the stroke length and table inclination were reduced to 2 $\mathrm{cm}$, and $4^{\circ}$, respectively, with increasing on table speed up to about 320-330 rpm. The overall table concentrate assayed $0.29 \% \mathrm{SnO}_{2}$ with a recovery reaching $96.94 \%$ from a feeding material containing $0.19 \% \mathrm{SnO}_{2}$. 
The heavy and the two middling products of the two size fractions $-0.50+0.21 \mathrm{~mm}$ and $-0.21+0.074$ $\mathrm{mm}$ were directed after dryness to dry high intensity magnetic separation using "Eriez" RER separator. At magnetic field strength approaching 21,000 gauss and feeding rate at $2 \mathrm{~kg} / \mathrm{hr}$, mathematically designed experiments were used to test the statistical significance of the main operating parameters of the RER separator (i.e. splitter inclination angle and belt speed) on the separation efficiency.

Taking the main factors effects and their interactions into account, the optimum conditions were found to be $72.50^{\circ}$ splitter inclination angle and $150 \mathrm{rpm}, 200 \mathrm{rpm}$ belt speed for the two size fractions $-0.50+$ $0.21 \mathrm{~mm}$ and $-0.21+0.074 \mathrm{~mm}$, respectively. Meanwhile, a high grade topaz mineral product was separated from the coarse fraction $-0.50+0.211 \mathrm{~mm}$, as a non-magnetic fraction at splitter angle $65^{\circ}$. At these optimum conditions, a cassiterite concentrate of $11.25 \%$ SnO2 with a recovery of $94.08 \%$ was obtained. Consequently, a high grade topaz mineral product was separated from the coarse fraction $0.50+0.211 \mathrm{~mm}$, as a non-magnetic fraction at splitter angle $65^{\circ}$. These results are highly imperative to achieve applicable processing flow-sheet of such kind of minerals' secondary resources.

\section{Declarations}

The authors have no relevant financial or non-financial interests to disclose.

The authors have no conflicts of interest to declare that are relevant to the content of this article.

All authors certify that they have no affiliations with or involvement in any organization or entity with any financial interest or non-financial interest in the subject matter or materials discussed in this manuscript.

The authors have no financial or proprietary interests in any material discussed in this article.

\section{References}

1. Angadi SI, Sreenivas T, Jeon H-S, Baek S-H, Mishra BK (2015) A review of cassiterite beneficiation fundamentals and plant practices. Minerals Engineering 70: 178-200. https://doi.org/10.1016/j.mineng.2014.09.009

2. Ajaka EO, Akande JM, Saliu MA (2014) Design of comminution circuit for optimum performance of the gravity separation unit at intake iron ore processing plant, Nigeria. Innovative Systems Design and Engineering 5 (6): 28 - 30. ISSN 2222-1727

3. Burt B, Mills C (1984) Gravity concentration technology. New York: Elsevier

4. Baba AA, Yusuf AO, Ragi MA, et al (2020) Potential of a Nigerian cassiterite ore for industrial Steel coatings. Rare Metal Technology 201-208, Part of the Minerals, Metals \& Materials Series book series (MMMS), TMS, Springer, Switzerland. https://doi.org/10.1007/978-3-030-36758-9

5. Bulatovic SM (2020) Handbook of Flotation Reagents: Chemistry, Theory and Practice, Flotation of sulfide ores: Volume 1. Elsevier Ltd. 
6. Box GEP, Behnken DW (1960) Some new three level designs for the study of quantitative variables. Technometrics 2, 455.

7. Dimova T, Aprahamian B, Marinova M (2019) Research of the magnetic field inside a drum separator with permanent magnets. $16^{\text {th }}$ Conference on Electrical Machines, Drives and Power Systems (ELMA). doi: https://doi.org/10.1109/elma.2019.8771679

8. Dalimunthe DY, Aldila H, Nuryadin A (2020) Optimization on the purification of cassiterite from lowgrade cassiterite concentrate. IOP Conf. Ser.: Earth Environ. Sci. 599 012002: 1-6. doi:10.1088/17551315/599/1/012002

9. El Aref M, Abd El-Rahman Y, et al (2020) Mineral Resources in Egypt (I): Metallic Ores, The Geology of Egypt. ( Springer Nature Switzerland AG 2020, Z. Hamimi et al. (eds.), Regional Geology Reviews, https://doi.org/10.1007/978-3-030-15265-9_14

10. Egbe EAP, Mudiare E, Abubakre OK, Ogunbajo MI (2013) Effectiveness of gravity separation methods for the beneficiation of Baban Tsauni (Nigeria) Lead Gold Ore. International Journal of Scientific and Research Publications 3 (5): 1-4. ISSN 2250-3153

11. EGSMA (1998) Metallogenic map of Arab Republic of Egypt, Metallic ores and non-metallic deposits, Scale 1:1,000,000. Egyptian geological survey and mining authority.

12. Falcon LM (1982) The gravity recovery of cassiterite. Journal of the South Africa Institute of Mining and Metallurgy: 112-117. ISSN 2250-3153

13. Gonzales LGV, Pino GAH, Torem ML (2013) Eletroflotation of cassiterite fines using a hydrophobic bacterium strain. REM: R. Esc. Minas, Ouro Preto 66 (4): 507-512.

14. Gehauf R (2004) A practical guide on selecting and optimizing rare earth magnetic separators. SME Annual Meeting, Denver, CO, USA.

15. Ibrahim SS, Farahat MM, Boulos TR (2017) Optimizing the performance of the RER magnetic separator for upgrading silica sands. Particulate Science and Technology: An International Journal 35 (1): 21-28, DOI: 10.1080/02726351.2015.1121179

16. Onyedika GO, Ogwuegbu MOC, Onuoha GN (2015) Energy potential of microwave heating: prior to and in leaching of low grade Kuru cassiterite ore in Jos, Nigeria. FUTO Journal Series 1 (1): 78-83.

17. Hisayoshi K, Uyeda C, Terada K (2016) Magnetic separation of general solid particles realized by a permanent magnet. Scientific Reports: 6 (1). doi: https://doi.org/10.1038/srep38431

18. Jiao H, Shib C, Ruixia Tian R (2011) Research on Design and Magnet Assembly Process of Multivariate and Multi-Roll Permanent Magnetic Separator. Advanced Materials Research 201-203: 486-490. doi:10.4028/www.scientific.net/AMR.201-203.486

19. Kumar N, Joshi B and Asokan K (2019) The effects of thermal annealing on the structural and electrical properties of zinc tin oxide thin films for transparent conducting electrode applications. Physica B: Condensed Matter 558: 5-9, Elsevier

20. Lalasari LH, A Suharyanto A, Firdiyono F (2017) The effect of pretreatments on the dissolutions of impurities from Indonesian cassiterite mineral. Journal of Physics: Conference Series 817, 012064, Jakarta, Indonesia 
21. Lungu, M. (2009) Separation of small nonferrous particles using a two successive steps eddy-current separator with permanent magnets. International Journal of Mineral Processing 93 (2): 172-178. doi: https://doi.org/10.1016/j.minpro.2009.07.012

22. Li Y, Yang F (2016) Research progress and development trend of permanent magnetic separators in China and Abroad. 3rd International Conference on Vehicle, Mechanical and Electrical Engineering (ICVMEE 2016), ISBN: 978-1-60595-370-0. https://doi.org/10.12783/dtetr/icvme2016/4873

23. Mouedhen I, Coudert L, Blais JF, Mercier G (2018) Study of factors involved in the gravimetric separation process to treat soil contaminated by municipal solid waste. Journal of Environmental Management 209: 23-36. https://doi.org/10.1016/j.jenvman.2017.12.020.

24. Nakahiro Y, Wakamatsu DT (1993) A study on the separation of fine cassiterite and quartz by liquidliquid extraction. XVIII International Mineral Processing Congress, ISBN: 978-0-949106-81-0, page 9.

25. Nandi A, Mandal S, et al (2019) Application of hybrid rGO-ITO bilayer TCO on a-Si solar cell for performance enhancement. IEEE J. Photovoltaics 9: 12-7. DOI: 10.1109/JPHOTOV.2018.2873707

26. Slusarek B, Zakrzewski K (2012) Magnetic properties of permanent magnets for magnetic sensors working in wide range of temperature. Przeglad elektrotechniczny (Electrical Review) 88 (7), 123126. ISSN 0033-2097

27. Saisinchai S, Boonpramote T, Meechumna $P$ (2016) Recovery of fine cassiterite from tailing dump in Jarin tin mine, Thailand. Engineering Journal 20 (4). DOI:10.4186/ej.2016.20.4.41

28. Su Z, Zhang Y, Liu B, Lu M, Li G, Jiang T (2017) Extraction and separation of tin from tin-bearing secondary resources: A Review. JOM 69(11): 2364-2372.

29. Shvedchykova I, Melkonova I, Romanchenko J (2020) Research of magnetic distribution in the working area of disk separator, taking into account an influence of materials of permanent magnets. EUREKA: Physics and Engineering: 1.

30. Sreenivas T, Padmanabhan NPH (2002) Surface chemistry and flotation of cassiterite with alkyl hydroxamates. Colloids and Surfaces A: Physicochemical and Engineering Aspects 205 (1-2): 47-59. https://doi.org/10.1016/S0927-7757 (01)01146-3

31. Tian M, Gao Z, et al (2018a) Selective flotation of cassiterite from calcite with salicylhydroxamic acid collector and carboxymethyl cellulose depressant. Minerals 8 (8): 316. https://doi.org/10.3390/min8080316

32. Tian M, Hu Y, Sun W, Liu R (2017b) Study on the mechanism and application of a novel collector complexes in cassiterite flotation. Colloids and Surfaces A: Physicochemical and Engineering Aspect 522: 635-641. https://doi.org/10.1016/j.colsurfa.2017.02.051

33. Tian M, Khoso SA, Wang L, Sun W, Zhang C, Hu Y (2019) Selective separation behavior and its molecular mechanism of cassiterite from quartz using cupferron as a novel flotation collector with a lower dosage of $\mathrm{Pb}^{2+}$ ions. Appl. Surf. Sci. 486: 228-238. https://doi.org/10.1016/j.apsusc.2019.05.039

34. Tian M, Liu R, et al (2018c) Activation mechanism of Fe (III) ions in cassiterite flotation with benzohydroxamic acid collector. Miner. Eng. 119: 31-37. 
https://doi.org/10.1016/j.mineng.2018.01.011

35. Tian M, Zhang C, Han H, et al (2018e) Effects of the preassembly of benzohydroxamic acid with Fe (III) ions on its adsorption on cassiterite surface. Miner. Eng. 127: 32-41. https://doi.org/10.1016/j.mineng.2018.07.019

36. Tripathy SK, Ramamurthy Y, et al (2010) Influence of shaking table process parameters on concentration of chromite plant tailings. In: Proceedings of the XI International Seminar on Mineral Processing Technology, Jamshedpur, India. (c) NML Jamshedpur, pp. 199-204

37. Pecina ET, Rodriguez M, Castillo P, Diaz V, Orrantia E (2009) Effect of Leptospirillum ferrooxidans on the flotation kinetics of sulphide ores. Minerals Engineering 22 (5): 462-468. https://doi.org/10.1016/j.mineng.2008.12.008

38. Wills BA, Napier-Munn TJ (2006) Mineral processing technology: an introduction to the practical aspects of ore treatment and mineral recovery. Seventh Ed, by Heinemans Ltd, Great Britain. Elsevier Science \& Technology Books. ISBN: 0750644508

39. Yang J , Shuai Z, Zhou W, Ma S (2019) Grinding optimization of cassiterite-polymetallic sulfide ore. Minerals 9(2): 134. https://doi.org/10.3390/min9020134).

40. Yang JG, Wu YT, Zhang XL (2014) Study on separation of tin from a low-grade tin concentrate through leaching and low-temperature smelting processes. Miner. Process. Extr. Metall. 123: 228-33. https://doi.org/10.1179/1743285514Y.0000000070

41. Zeng S, Zeng W, Ren L, An D, Li H (2015) Development of a high gradient permanent magnetic separator (HGPMS). Minerals Engineering 71: 21-26. https://doi.org/10.1016/j.mineng.2014.10.009).

42. Zhang L, Khoso SA, Tian M, Sun W (2021) Cassiterite recovery from a sulfide ore flotation tailing by combined gravity and flotation separations. Physicochem. Probl. Miner. Process. 57(1): 206-215. DOI: $10.37190 / p p m p / 131006$

43. Zhou Y, Tong X, Song S, Wang W (2014) Beneficiation of cassiterite fines from a tin tailing slime by froth flotation. Sep. Sci. Technol. 49: 458-463. https://doi.org/10.1080/01496395.2013.818036

44. Zong QX, Fu LZ, Bo L (2018) Variables and applications on dry magnetic separator. $3^{\text {rd }}$ International Conference on advances in Energy and Environmental Research 53. https://doi.org/10.1051/e3sconf/20185302019

\section{Figures}




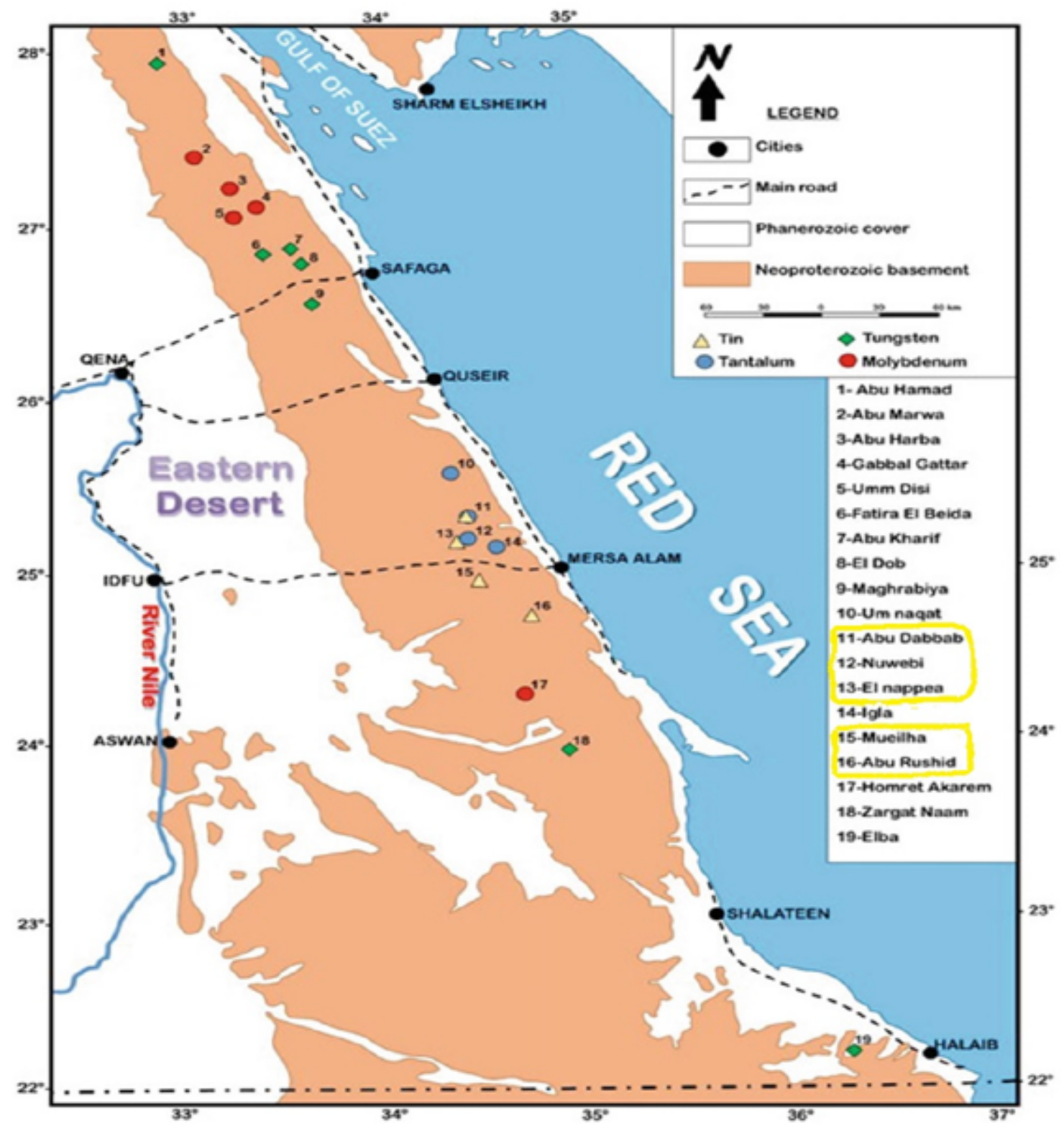

Figure 1

Occurrences of cassiterite deposits in the Eastern Desert of Egypt (EGSMA 1998) 


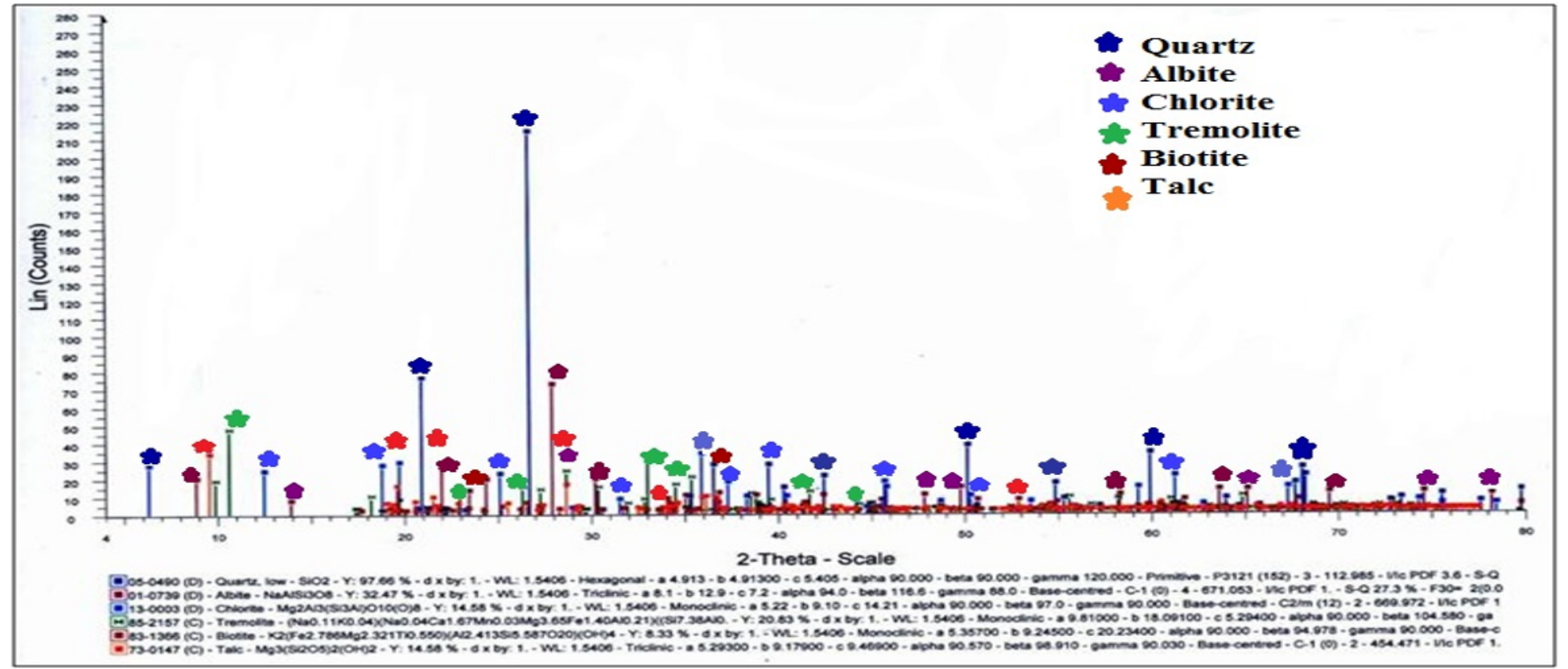

Figure 2

XRD analysis of the original sample

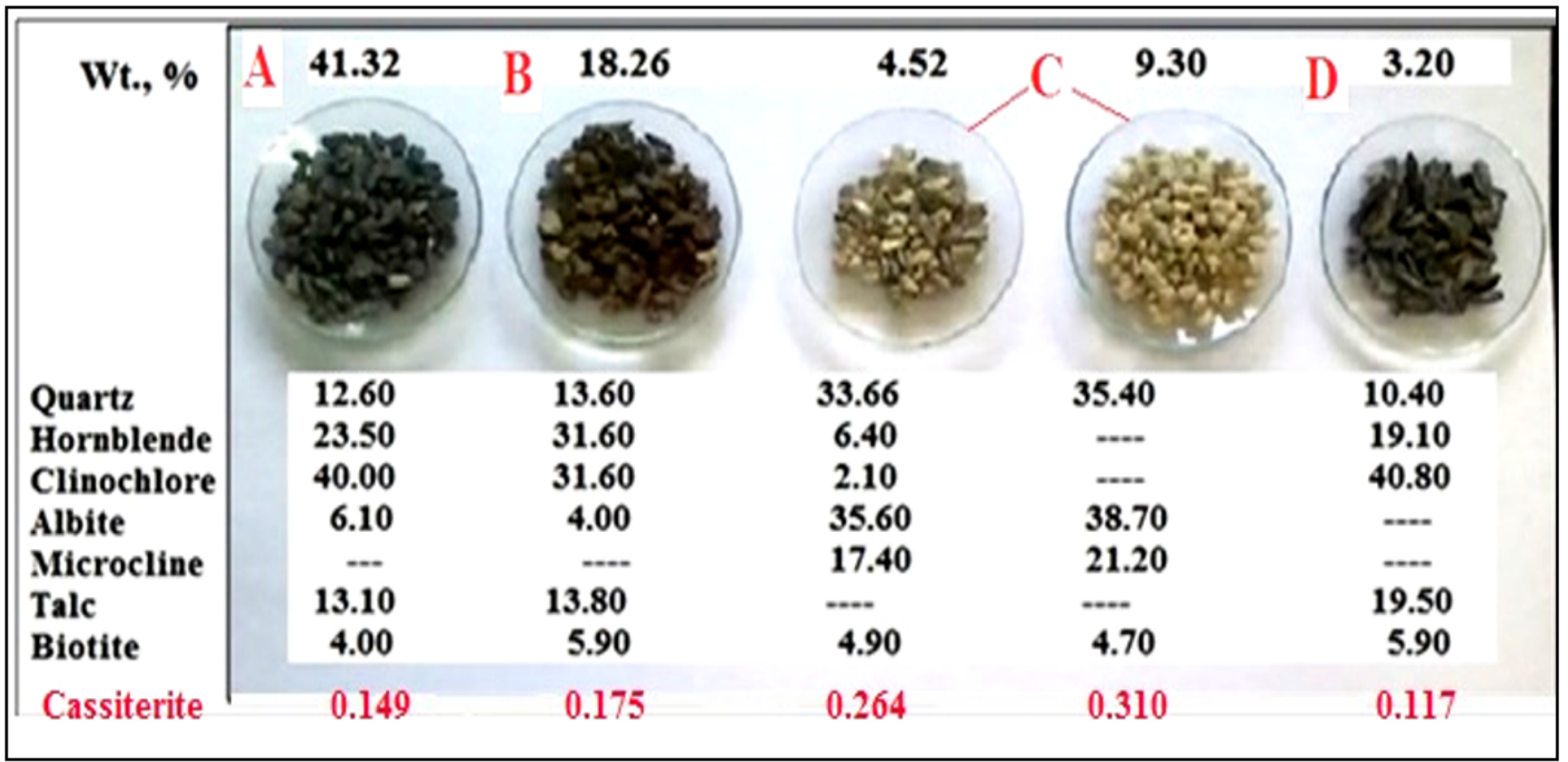

Figure 3

Major components of $-6.0+2.23 \mathrm{~mm}$ original fraction 


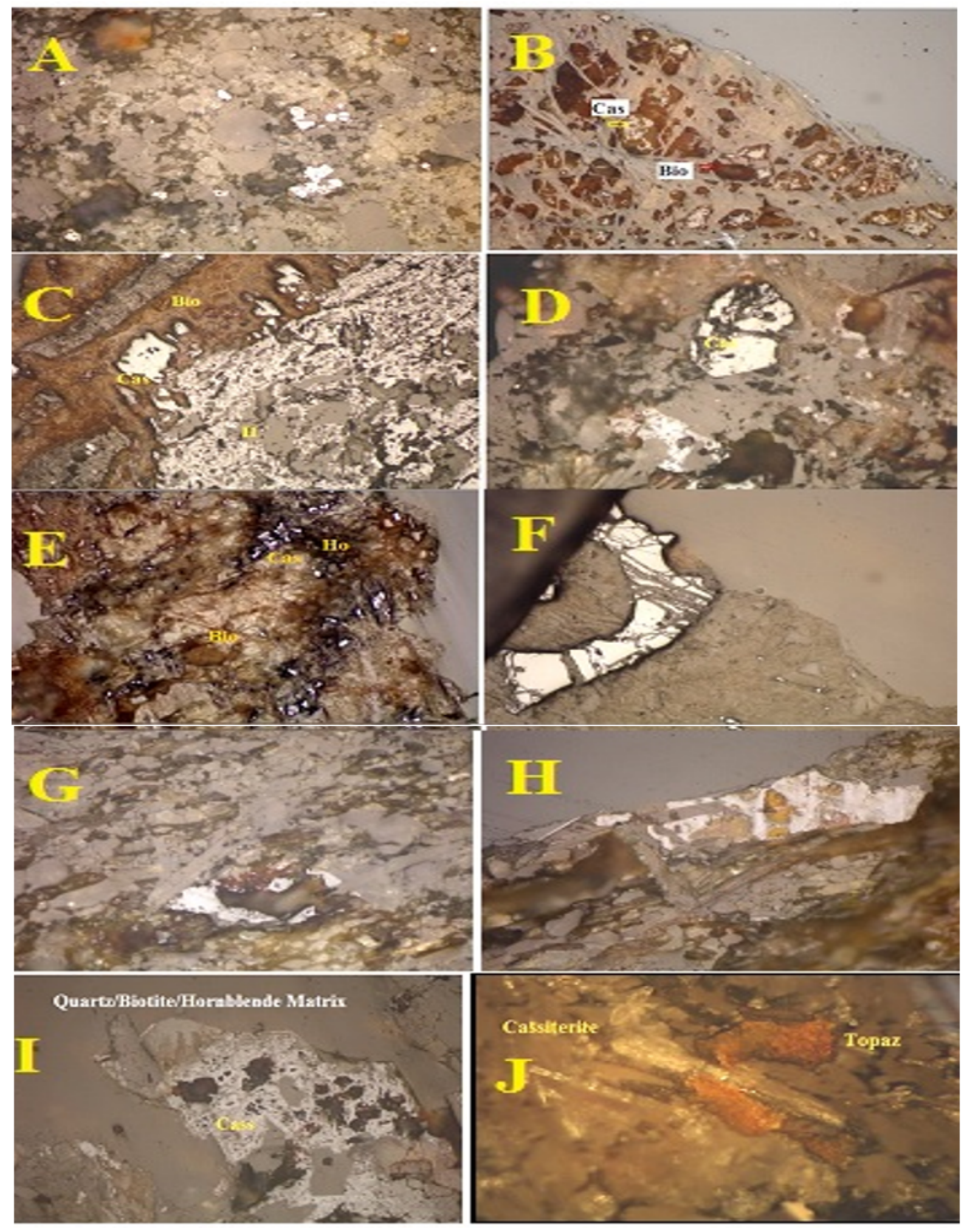

Figure 4

Petrography pictures of cassiterite inclusions within different granitic matrices 


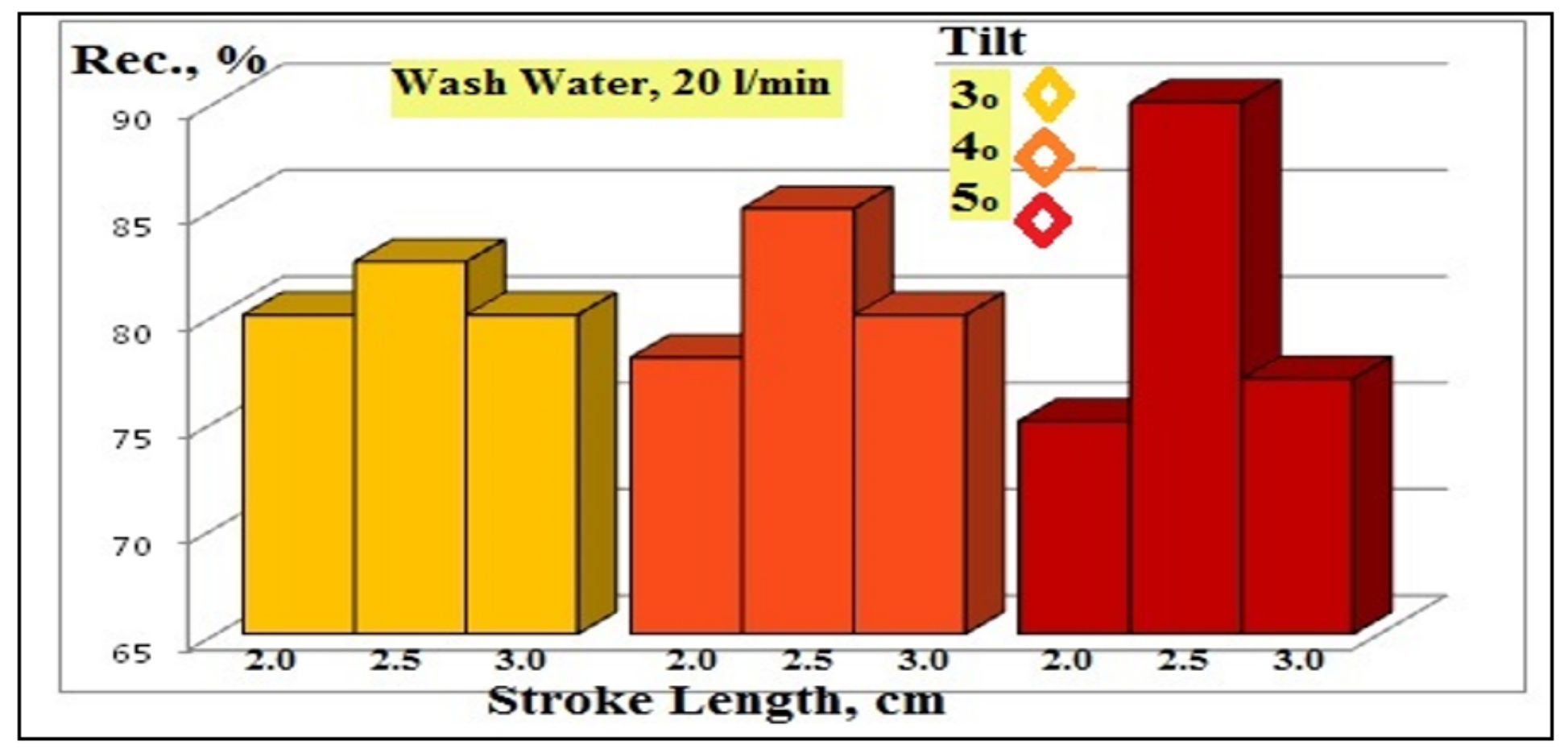

Figure 5

Effect of stroke length at different table inclinations on cassiterite recovery\%

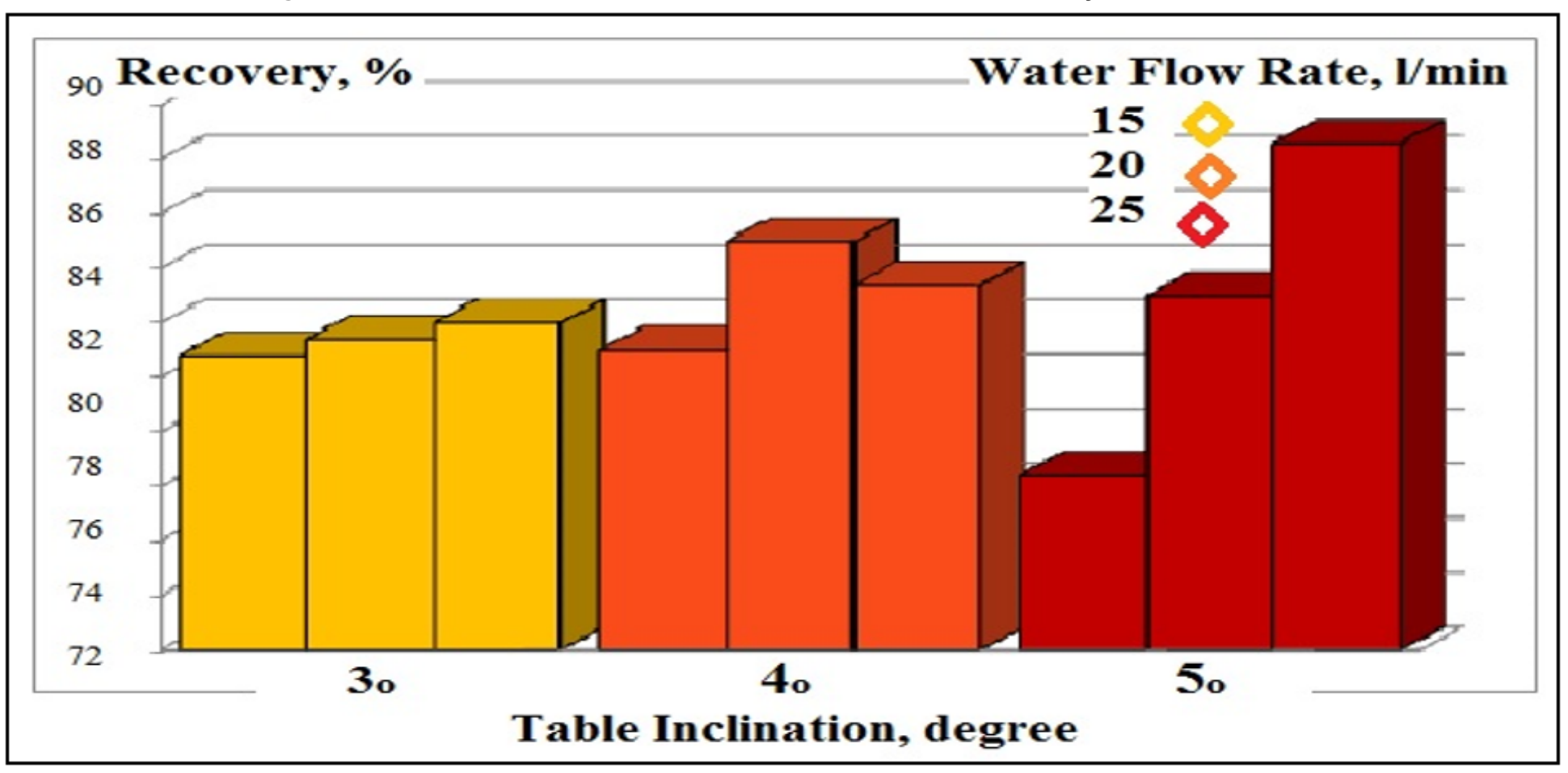

Figure 6

Effect of table inclination at different water flow rates on cassiterite recovery\% 


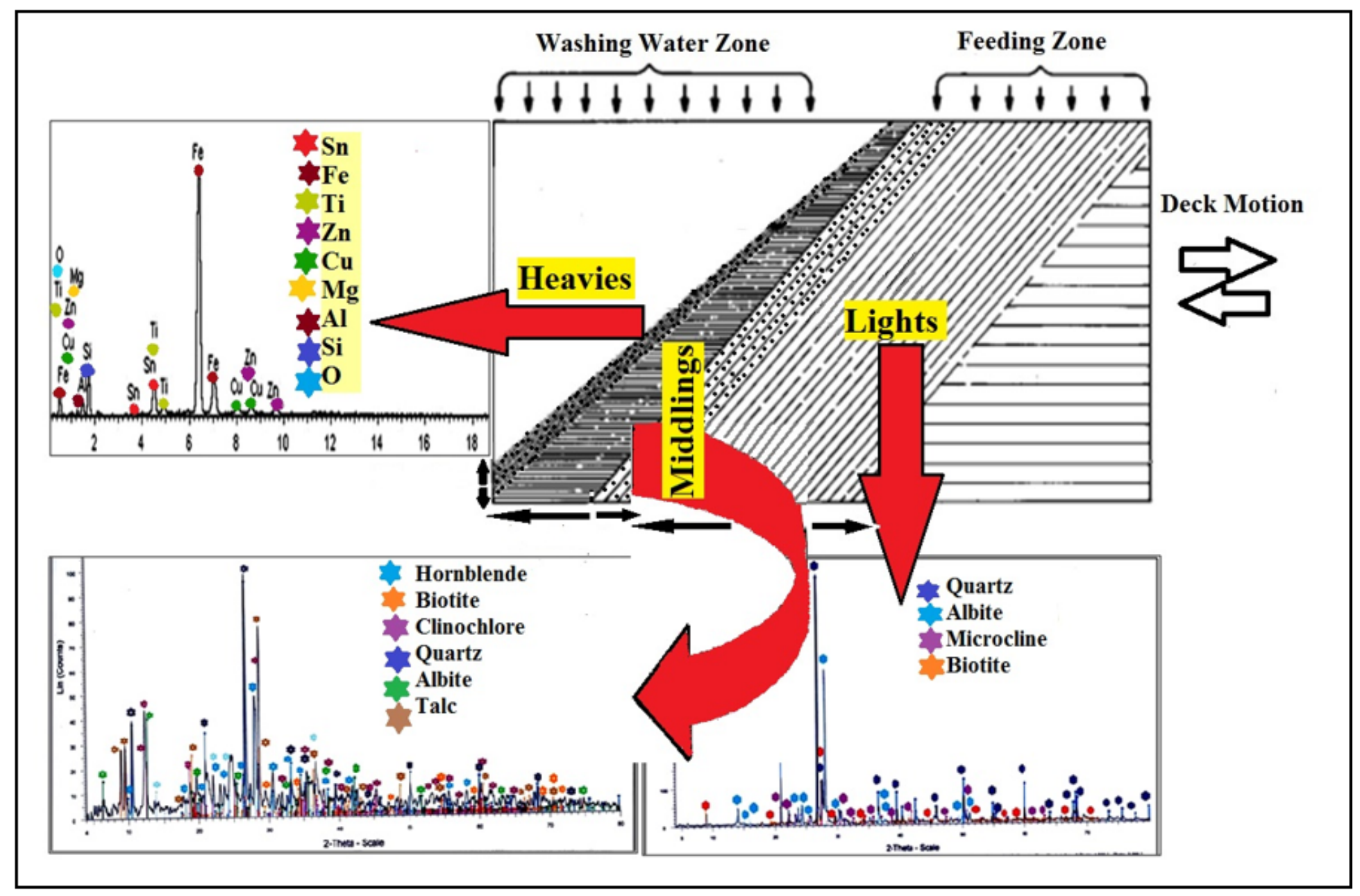

Figure 7

Schematic diagram showing the shaking tabling separation process 


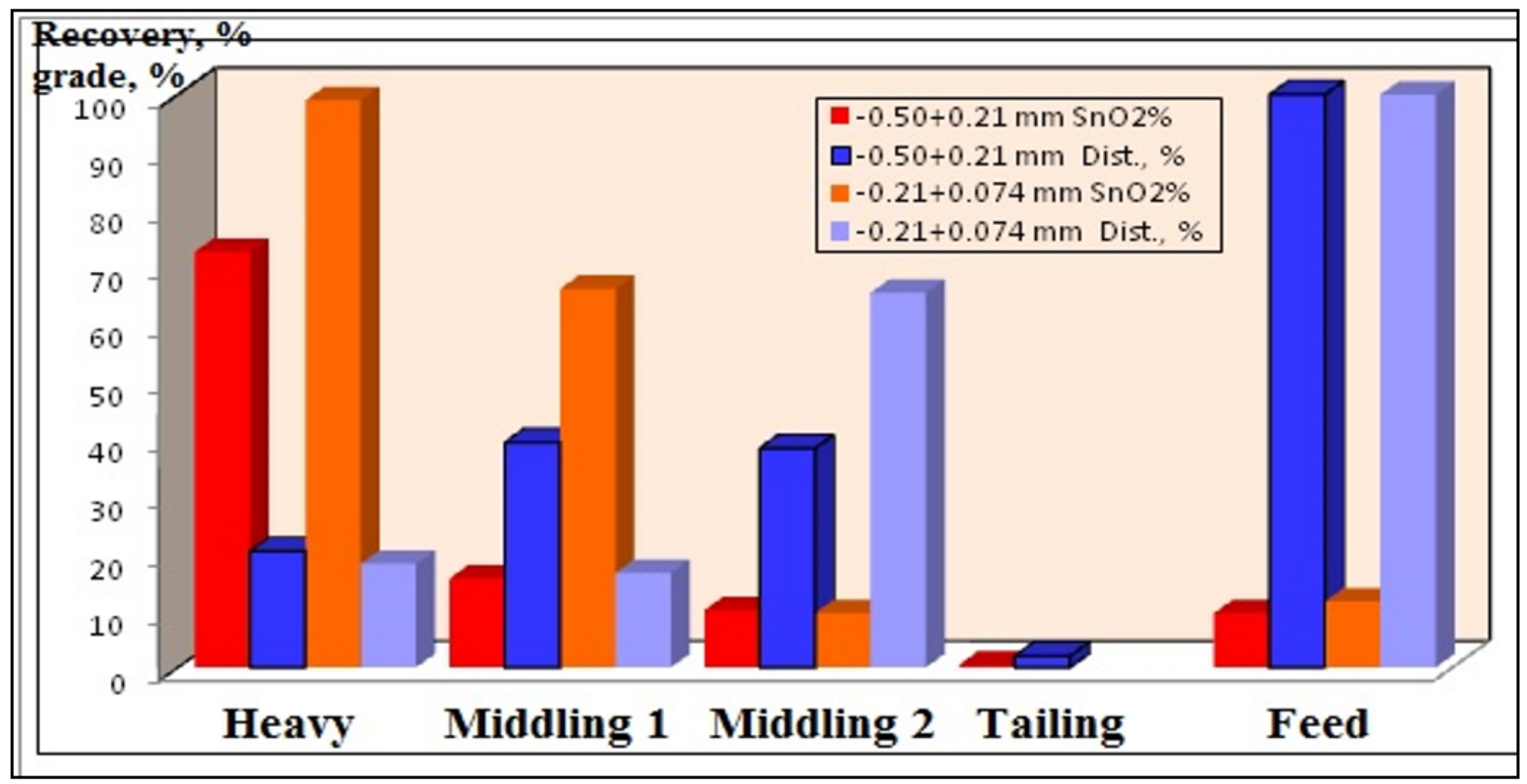

Figure 8

Schematic diagram showing the evaluation of the shaking tabling end-products with respect to cassiterite recovery and grade 


\section{Normal plot of residuals}

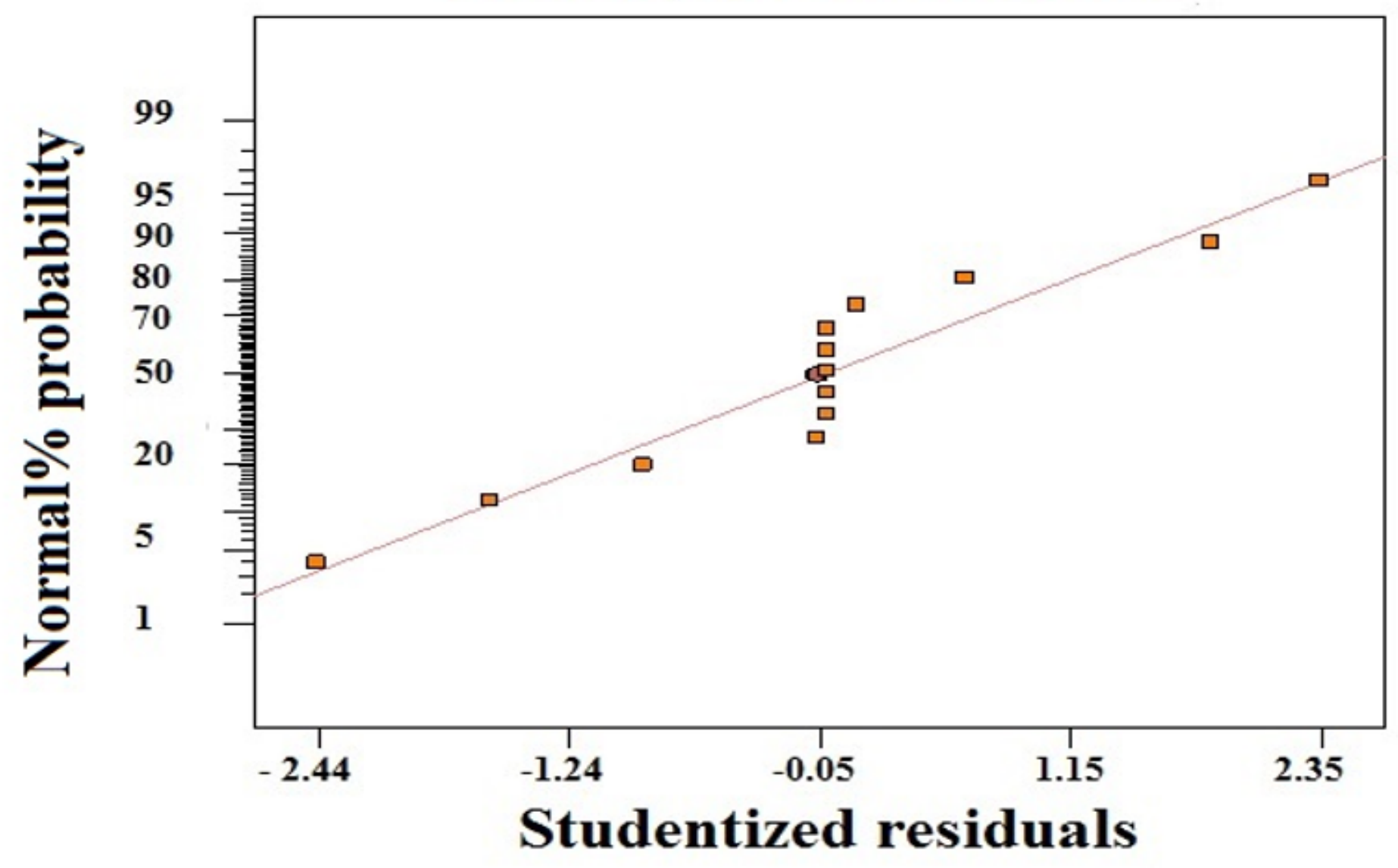

Figure 9

Normal plot of residuals

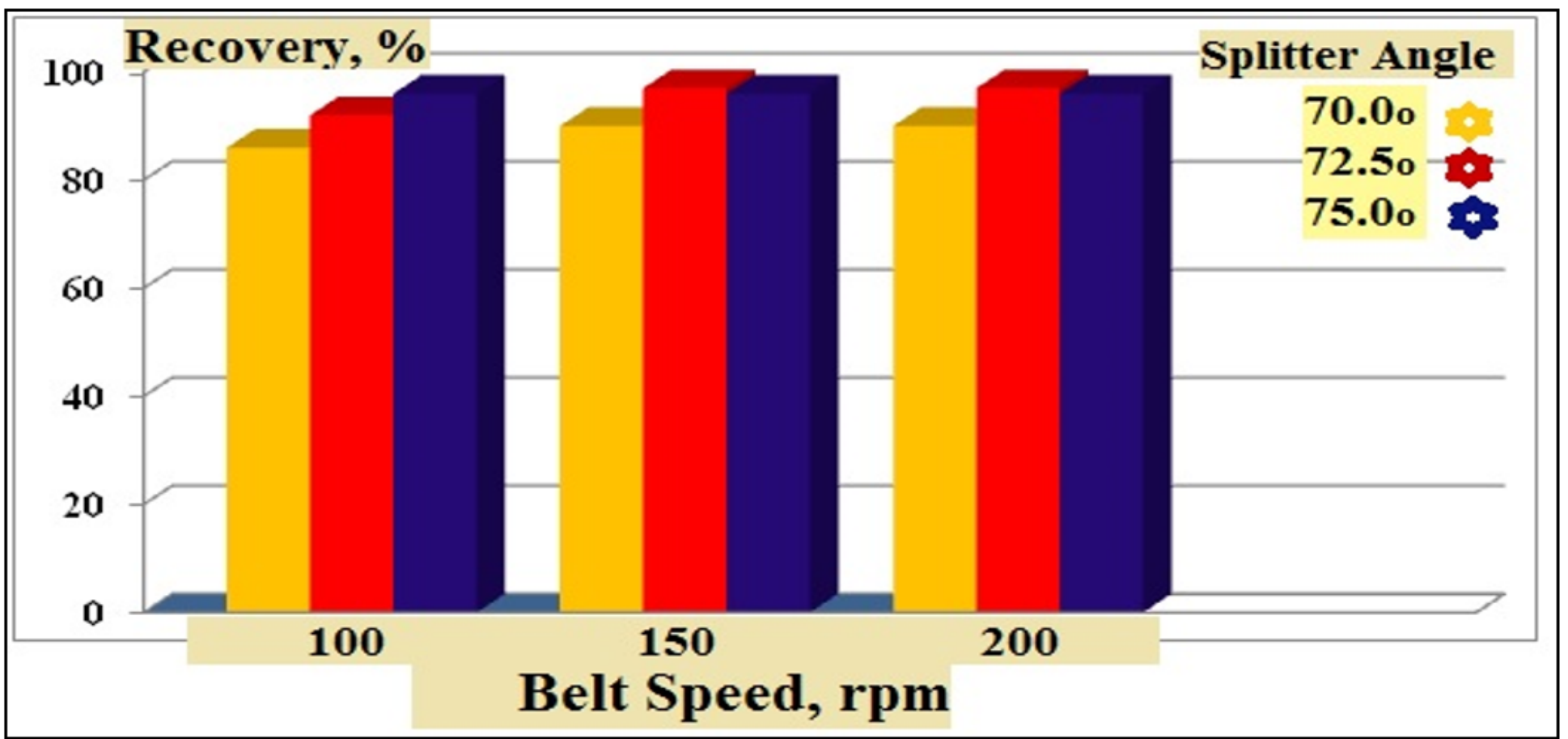


Figure 10

Effect of belt speed at different splitter angles on cassiterie recovery\%

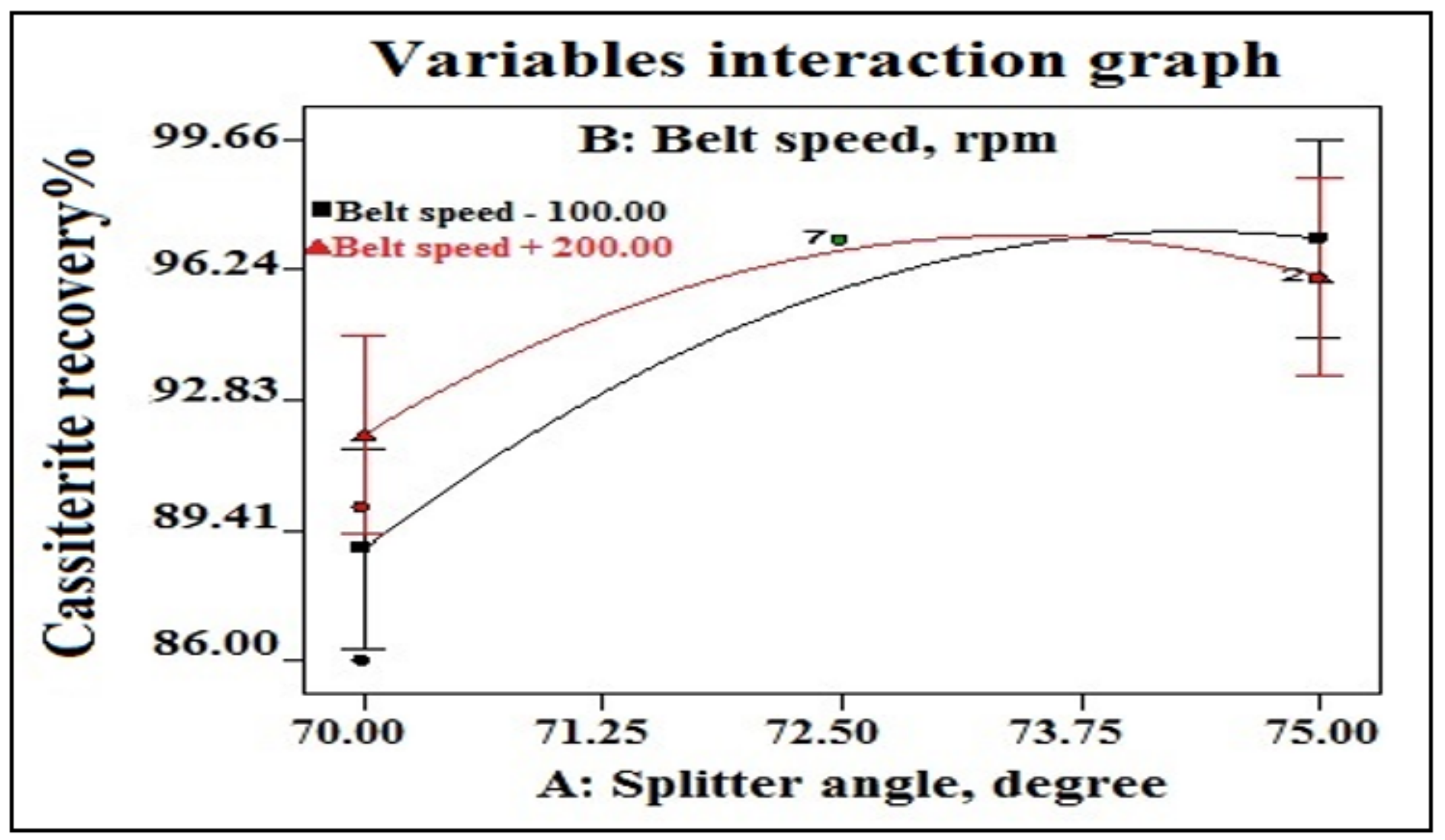

Figure 11

Variables interaction effect on cassiterite recovery\% 


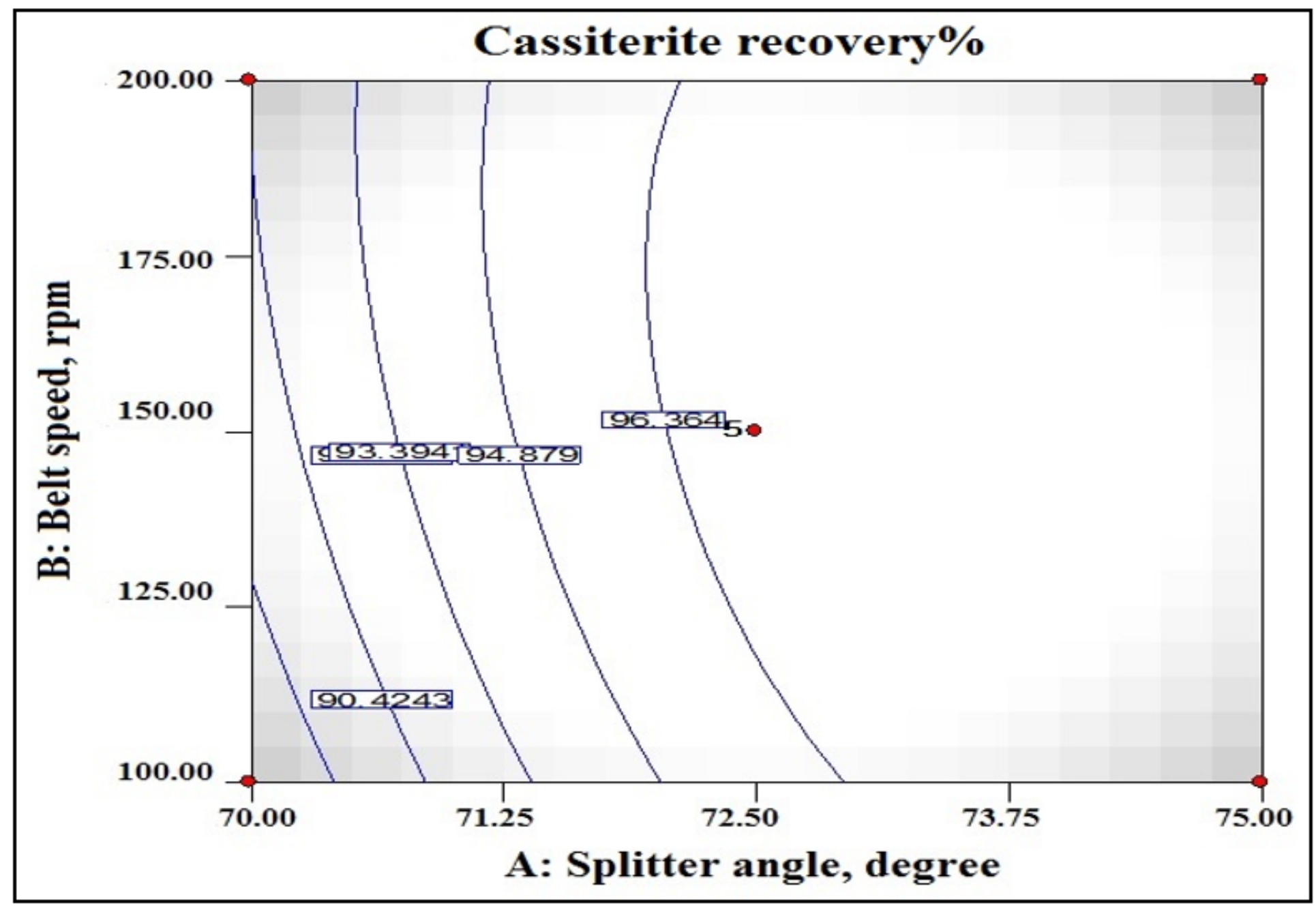

Figure 12

Effect of both variables on cassiterite recovery\% 


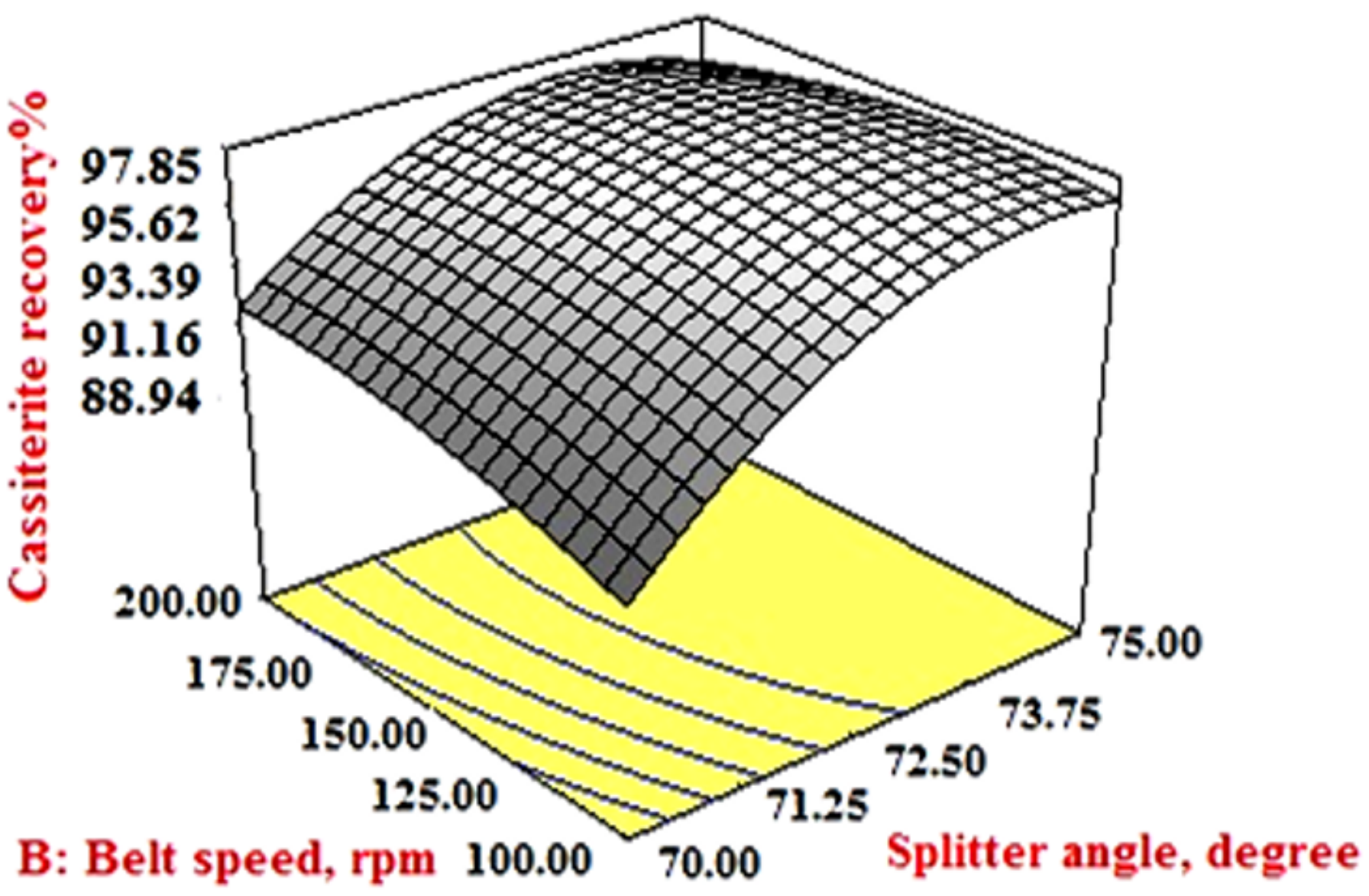

Figure 13

Response surfaces for cassiterite recovery\% as function of RER magnetic separation variables 


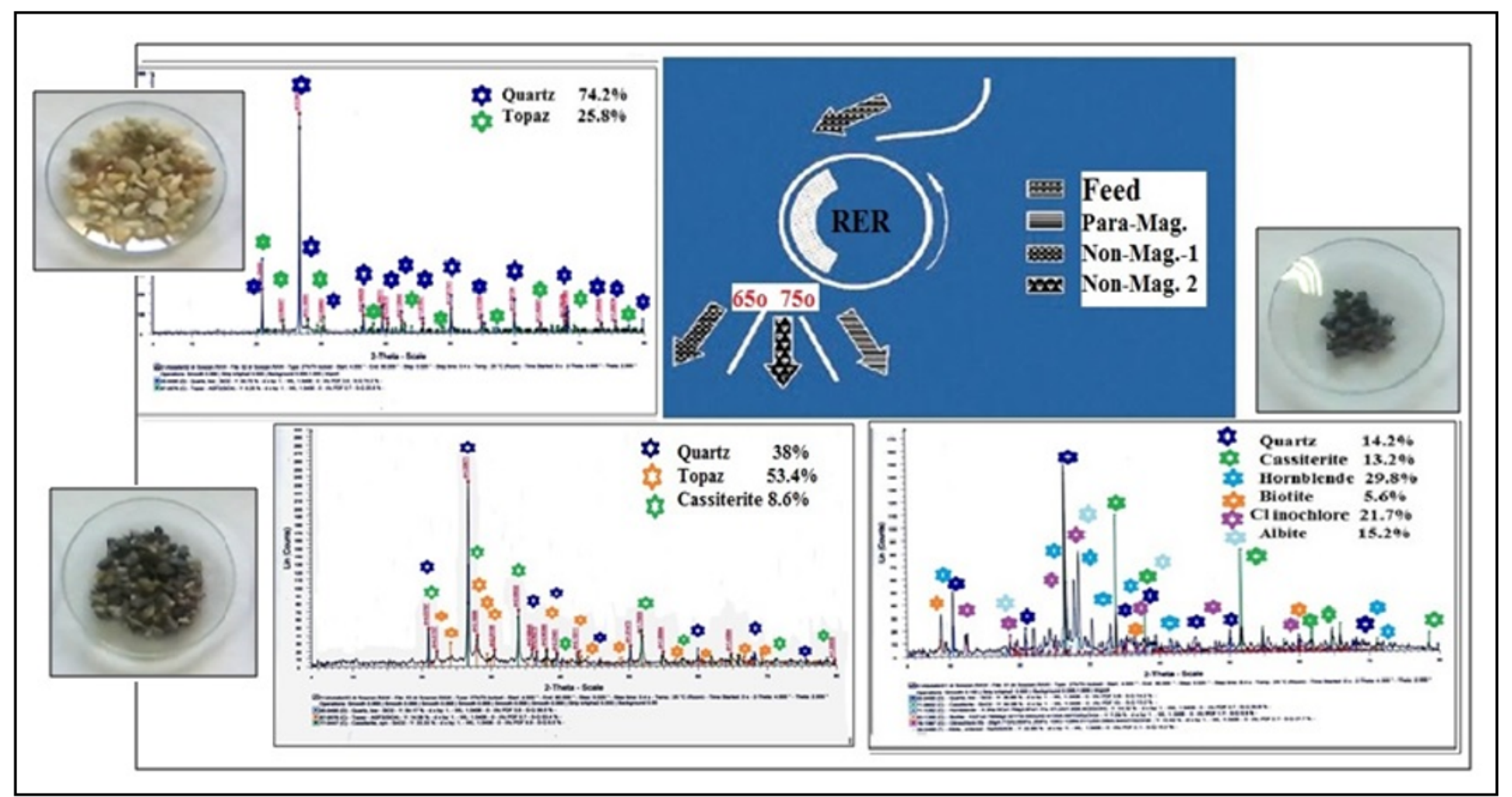

Figure 14

Schematic diagram showing the results of the dry RER magnetic separation processes of the coarse size fraction $-0.50+0.21 \mathrm{~mm}$

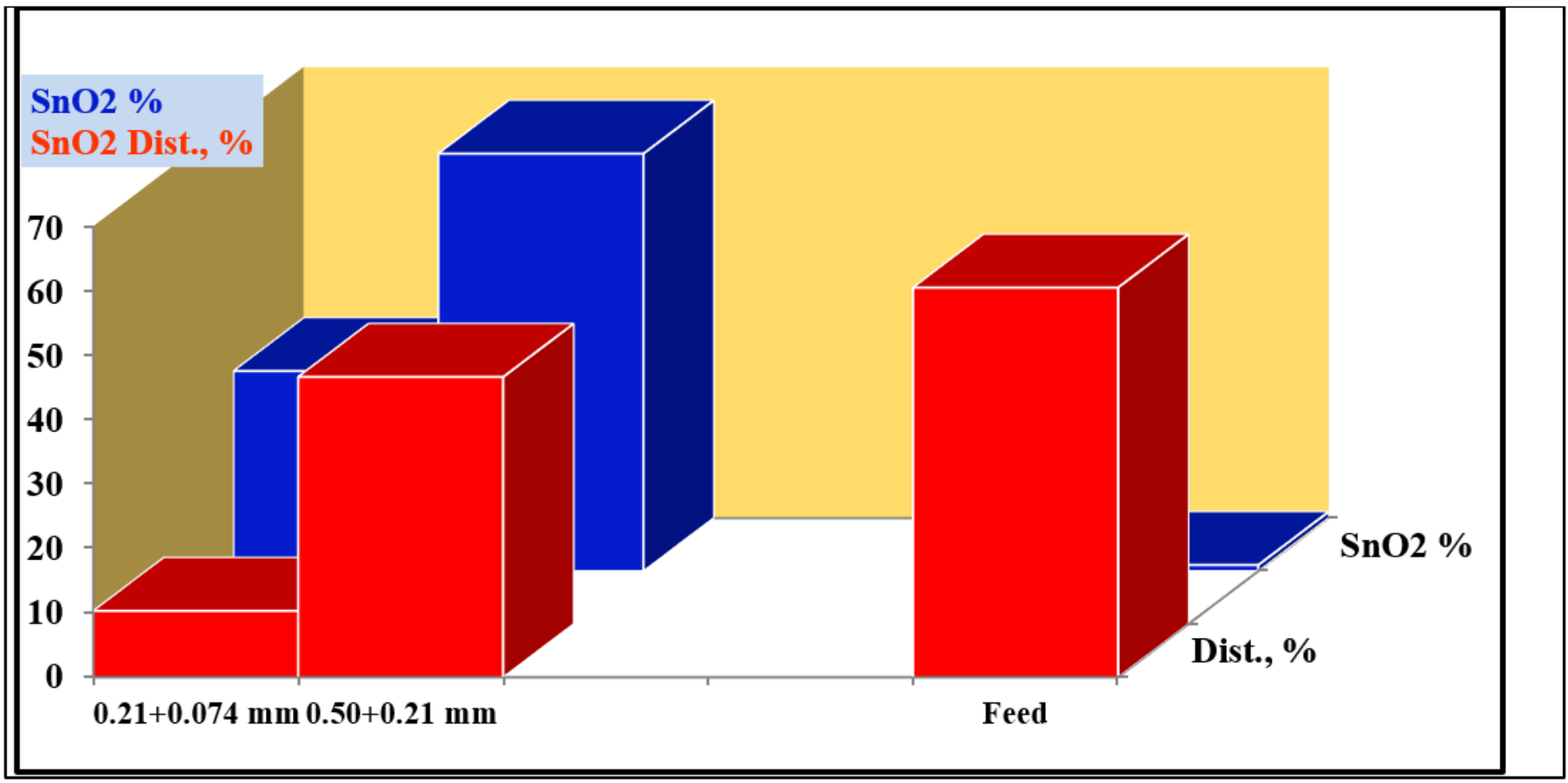

Figure 15 
Schematic diagram showing the results of the dry RER magnetic separation processes of the two size fractions

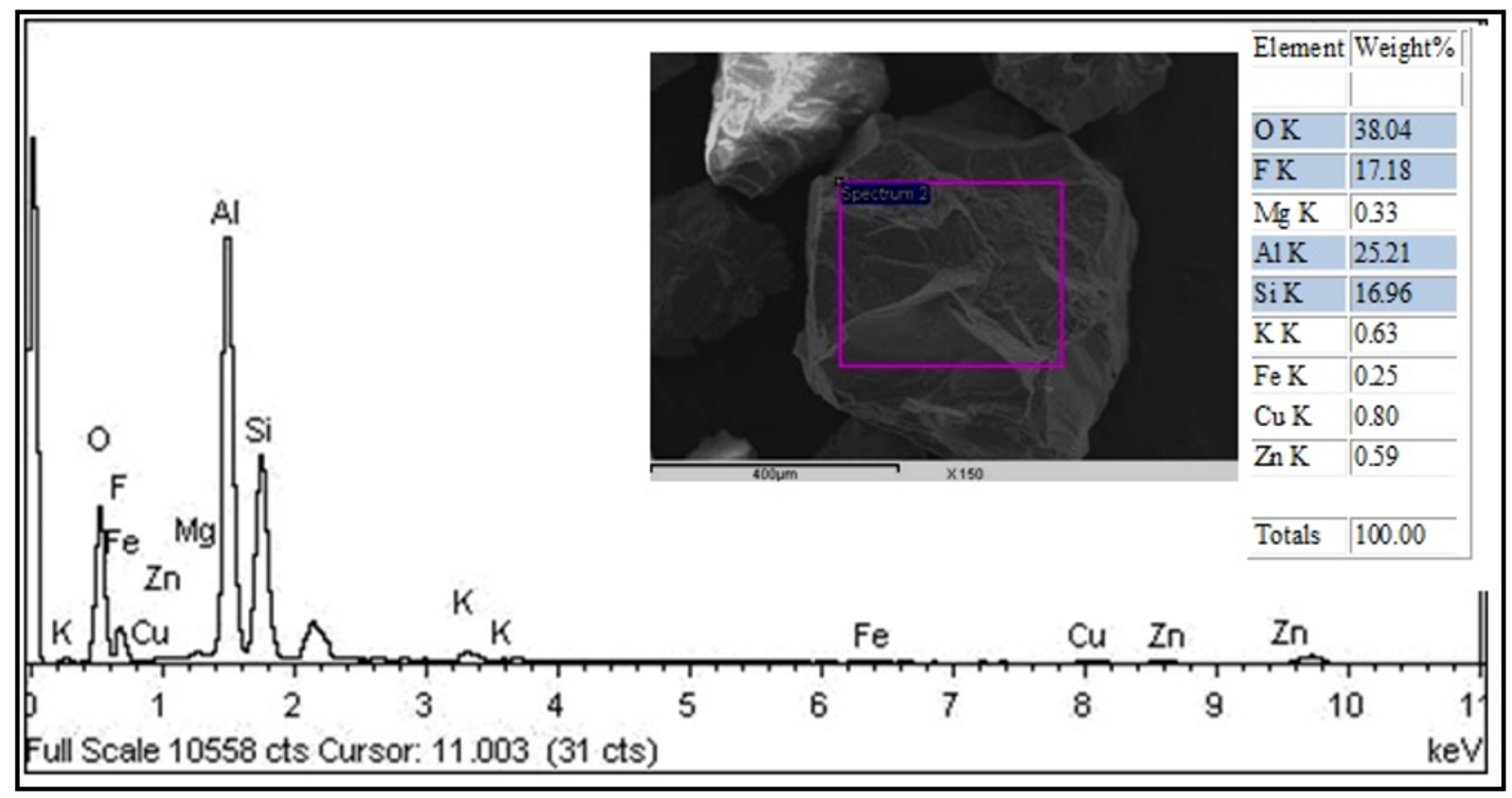

Figure 16

SEM/EDX analyses of topaz mineral

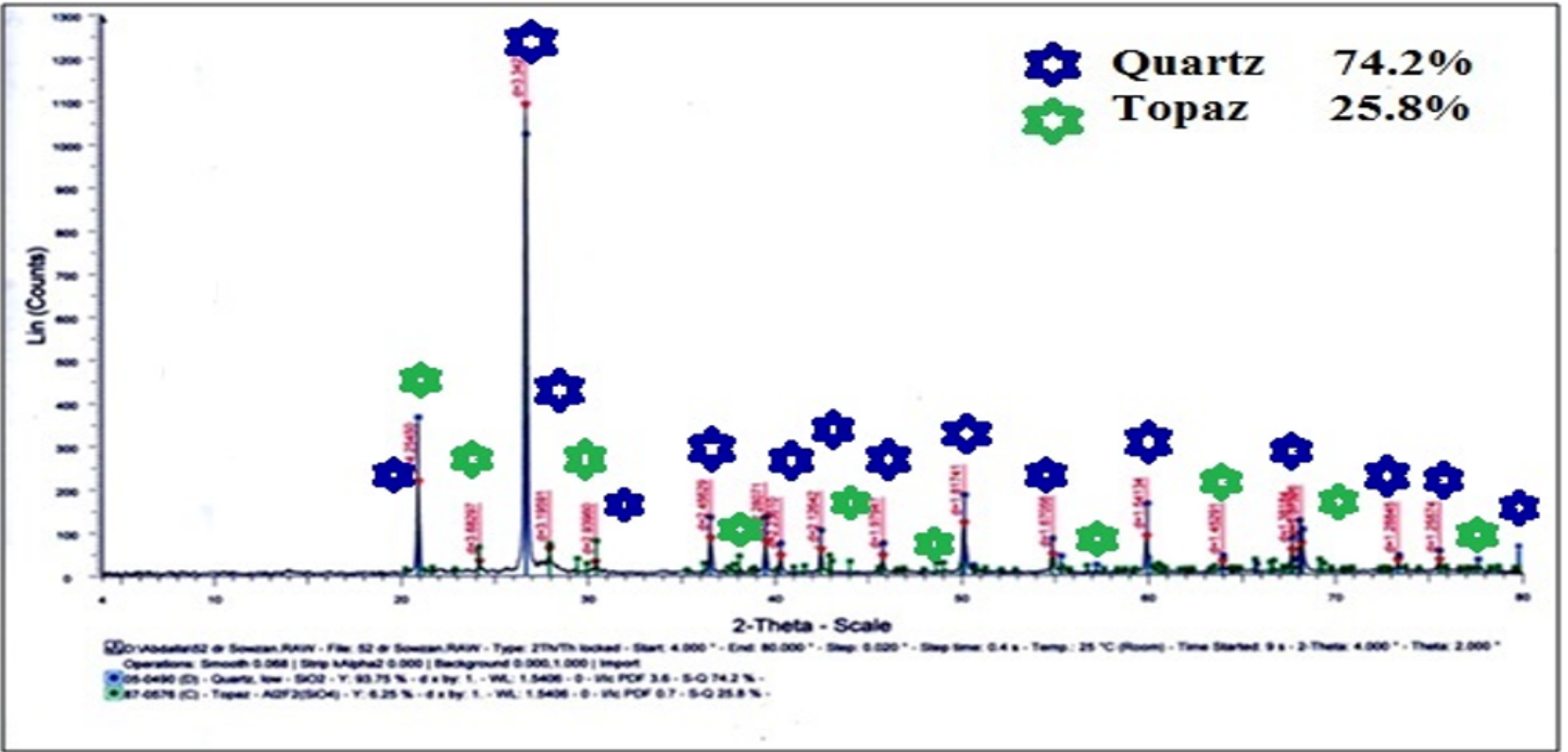

Figure 17 
XRD analyses of topaz concentrate

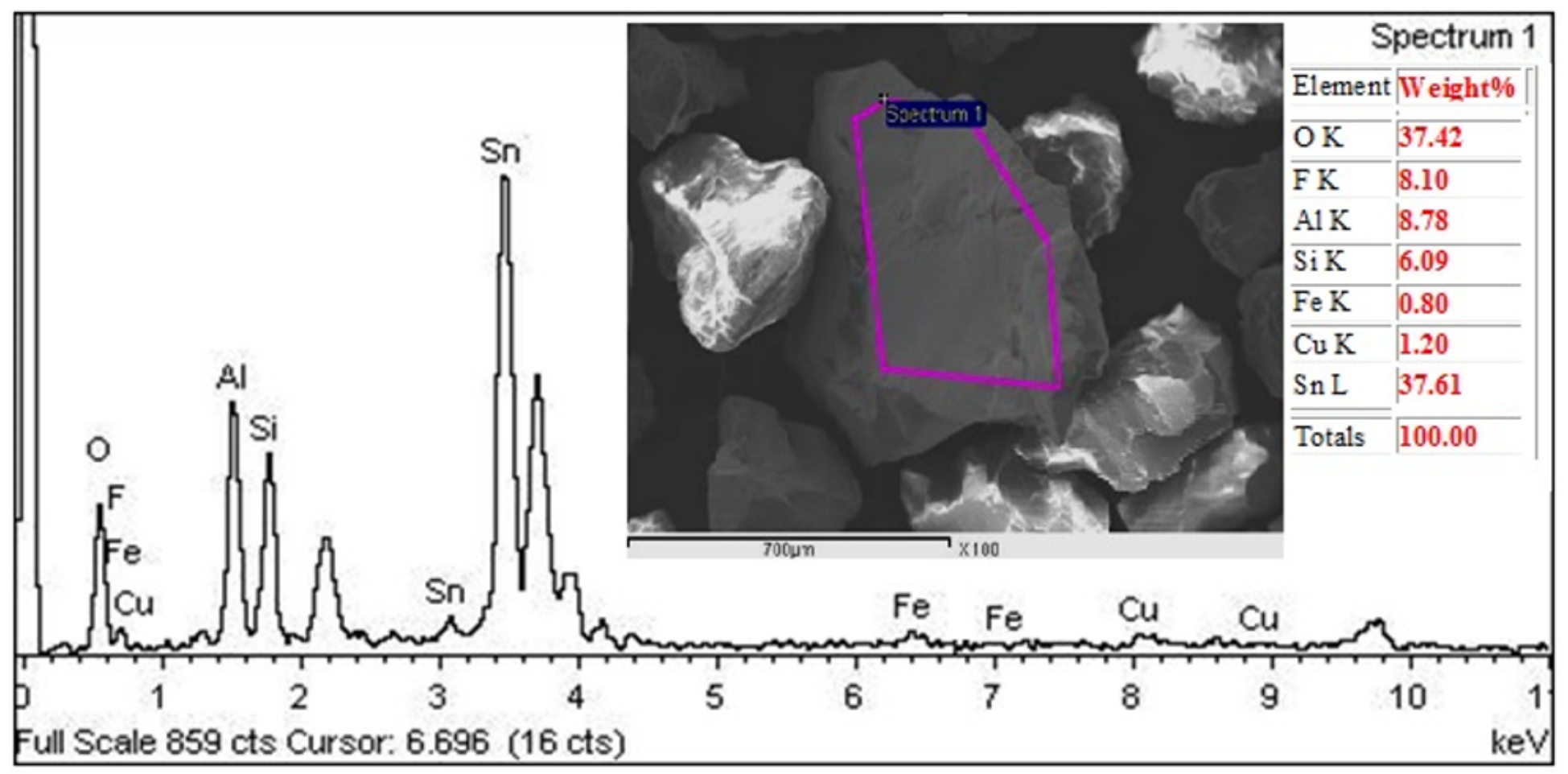

Figure 18

SEM/EDX analyses of cassiterite/topaz minerals

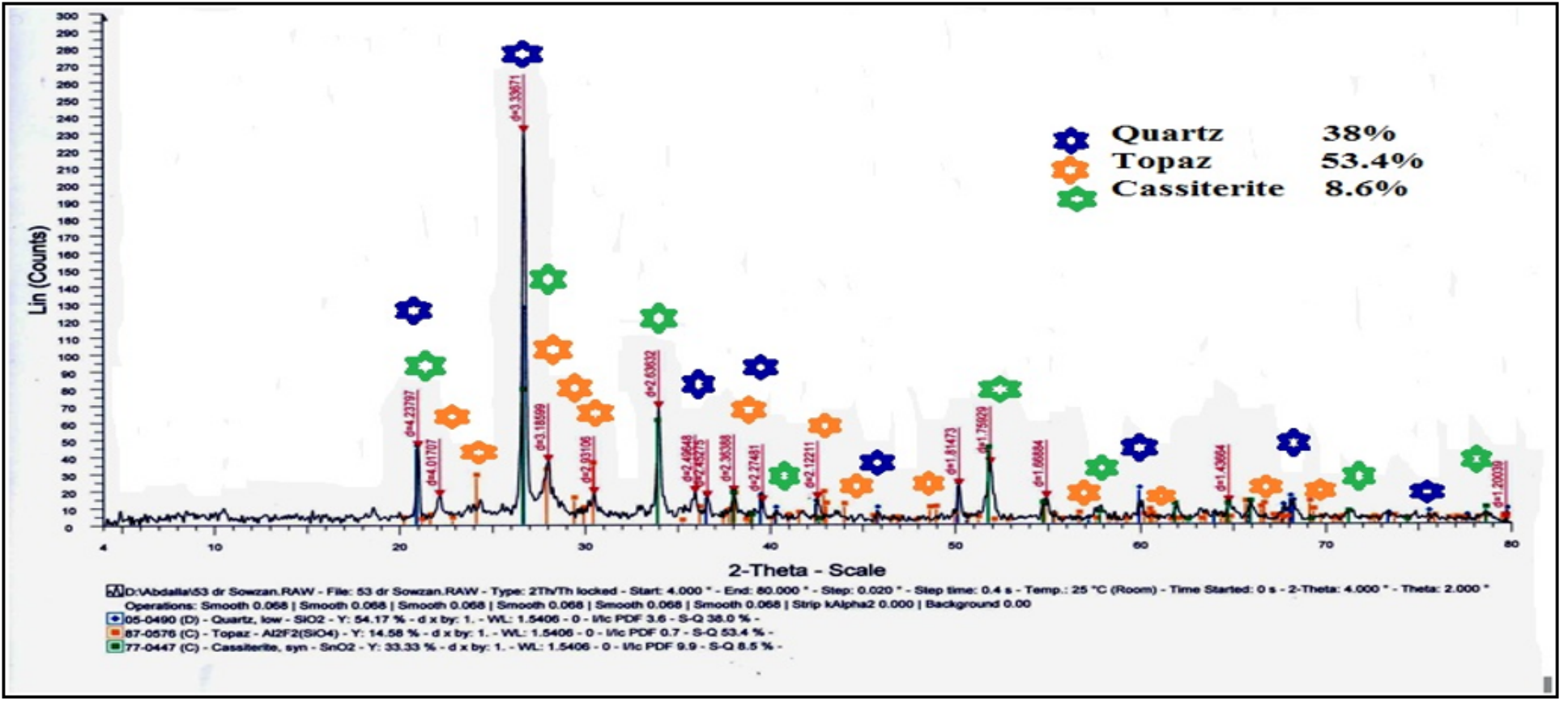

Figure 19

XRD of cassiterite/topaz concentrate 


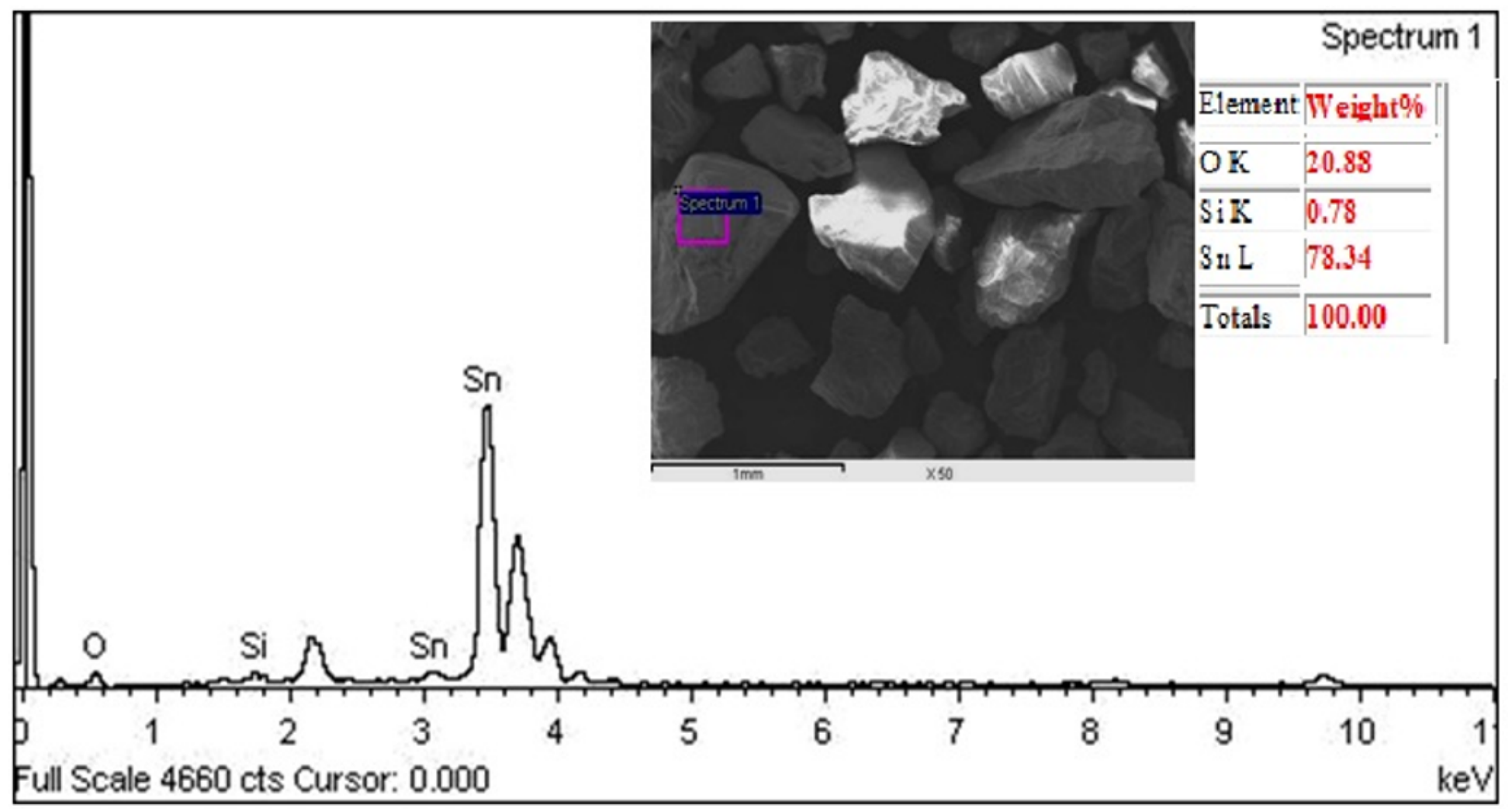

Figure 20

SEM/EDX analyses of cassiterite mineral

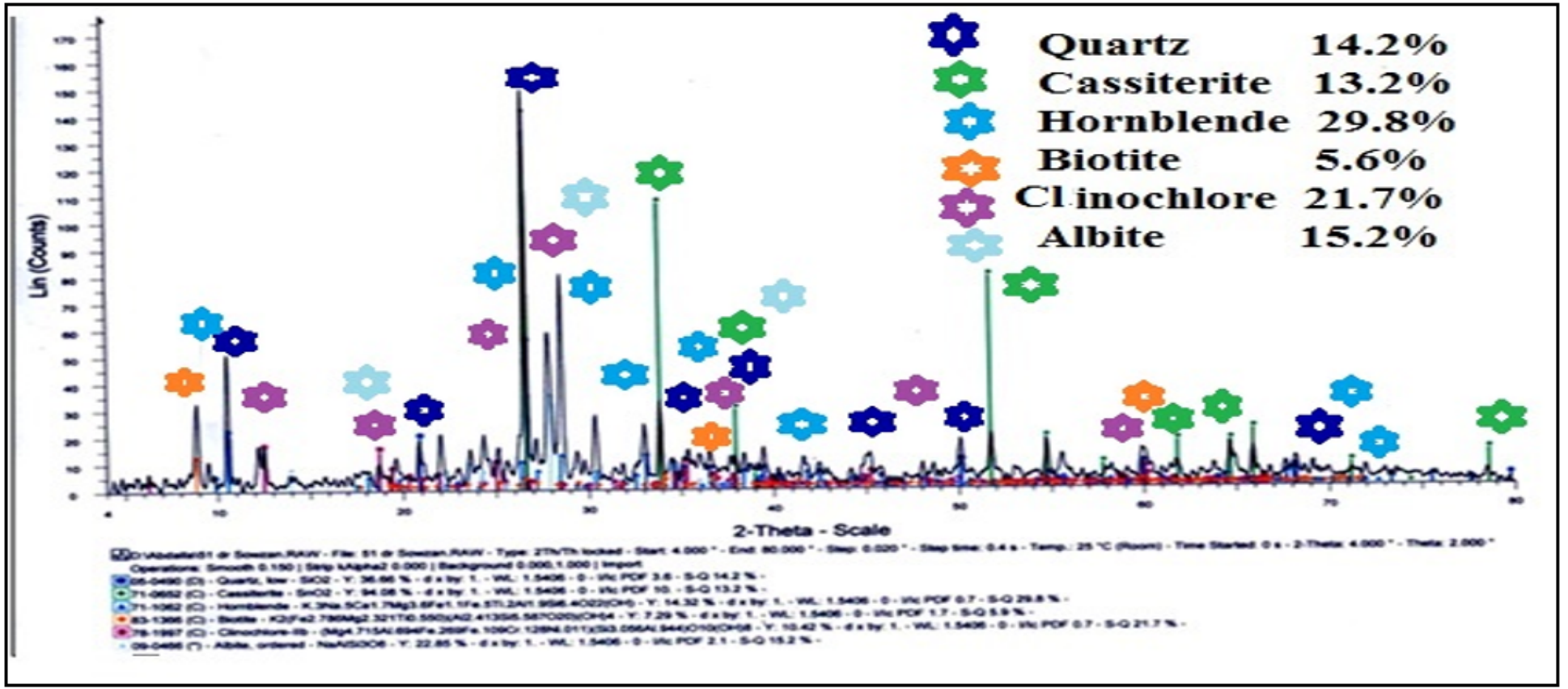

Figure 21

XRD of cassiterite concentrate 


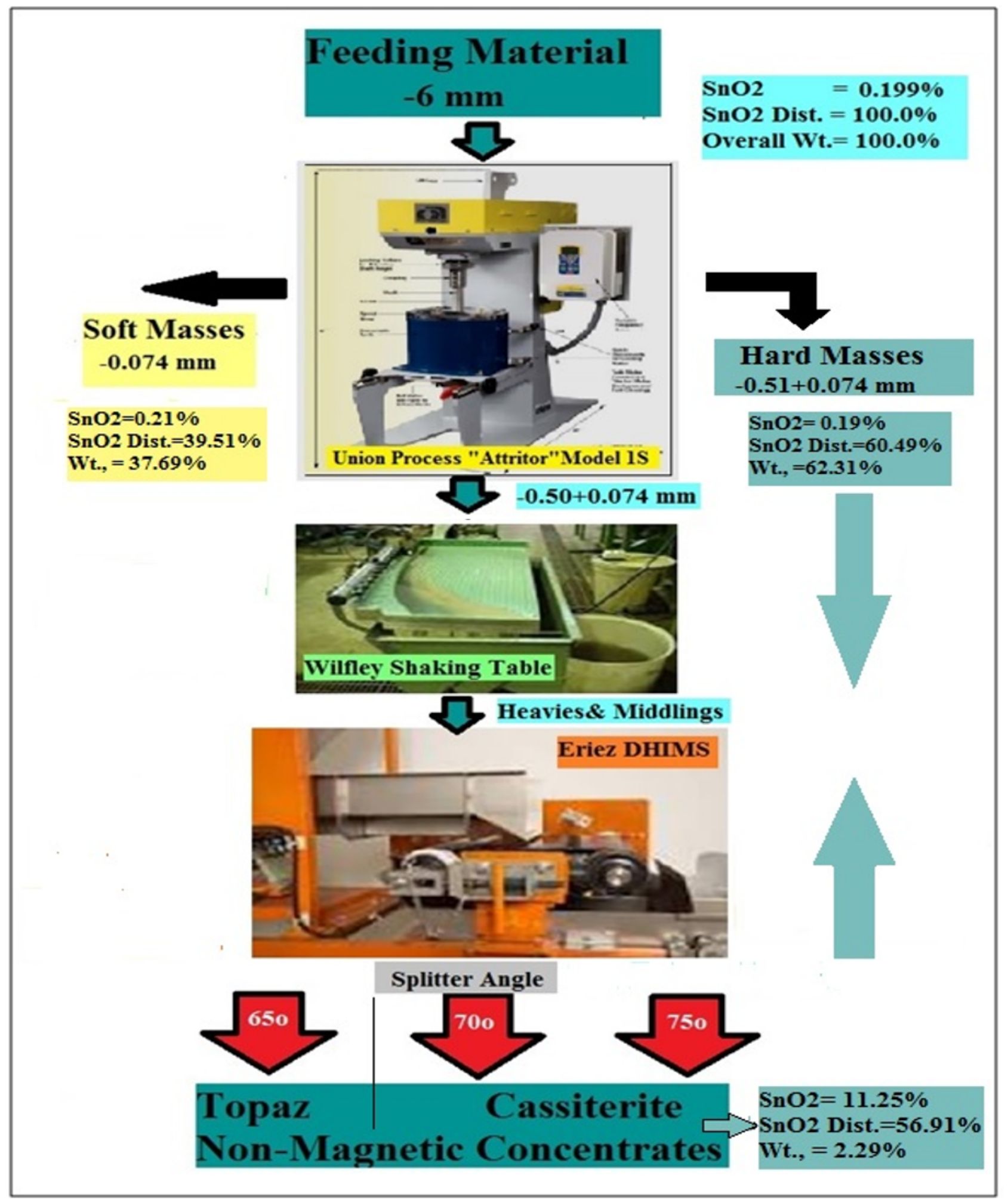

Figure 22

Final processing flow-sheet 